\title{
Tradução, teorização, traição. Ensaio sobre estudos de tradução, de Gauti Kristmannsson
}

Luciano Dutra ${ }^{1}$

Resumo: Nesta colaboração, o leitor encontrará o original islandês do ensaio “Teoría, tryggð og túlkun”, de Gauti Kristmannsson, seguido pela tradução do referido texto para o português.

\section{Apresentação}

Nascido em 12 de setembro de 1960 em Reykjavík (Islândia), Gauti Kristmannsson é professor de estudos de tradução na Universidade da Islândia, onde colou grau de bacharel em Letras (inglês) em 1987, ano em que foi credenciado como tradutor público e intérprete juramentado inglês-islandês pelo ministério do interior da Islândia. Mestre summa cum laude em literatura escocesa pela Universi-

1 Nascido em Viamão/RS (1973). Naturalizado islandês (2007). Bacharel em Letras Islandesas (2007) e mestrando em Estudos da Tradução na Universidade da Islândia (Háskóli Íslands). Tradutor juramentado islandês-português (2008). Autor de uma monografia (2007) e um roteiro de documentário (2013) sobre a imigração islandesa no Brasil no fim do século XIX. Além de literatura islandesa e nórdica contemporâneas, traduz as sagas, obras únicas de prosa de ficção compiladas na Idade Média por autores anônimos da Islândia. Fundou (2014) em Reykjavík a Sagarana forlag, editora plurilíngue que enfoca a publicação de literatura em tradução entre as línguas nórdicas e o português. Fundou (2016) a página Um poema nórdico ao dia (www.facebook.com/nordrsudr), que publica diariamente poemas de autores de todos os países nórdicos, a maioria deles até então inéditos em português, sempre em tradução direta dos idiomas originais. Pela boca da Baleia, sua tradução do romance Rökekurbýsnir, do islandês Sjón, ficou em segundo lugar no prêmio Paulo Rónai da Biblioteca Nacional e foi uma das dez finalistas do Prêmio Jabuti (2018). Participou como tradutor do Festival Internacional de Literatura de Reykjavík (2017), da Feira do Livro de Porto Alegre (2017), da Feira do Livro de Gotemburgo (2017-2018), da etapa de Zurique da Primavera Literária Brasileira (2019) e da Feira do Livro das Ilhas Feroés (2019). 
dade de Edimburgo em 1991 e doutor summa cum laude em estudos de tradução, inglês, alemão e sociologia da cultura pela Universidade Johannes Gutenberg em Mainz/Germersheim no ano 2001. As áreas de interesse de Gauti são os estudos de tradução em geral, literatura em língua inglesa e alemã, iluminismo europeu, história da tradução, políticas linguísticas na Islândia e noutros países e literatura islandesa contemporânea. 


\section{Teoría, tryggð og túlkun ${ }^{2}$}

Gauti Kristmannsson

Der Autor hat den Mund zu haltern, wenn sein Werk den Mund auftut.

Friedrich Nietzsche

\section{Aðfararorð}

Dýðingar eru pversagnarkennt athæfi. Frá orði til gerðar og aftur til orðas liggur oft langur og villugjarn vegur, örðugur yfirferðar og sérstakur fyrir pá sök að ekki verður litið um öxl í von um að finna leiðina til baka. Einhvers staðar á pessari leið er hyldýpi sem brúa verður ef yfir á að komast. Brúargerðin er pað sem flestir kalla pýðingar, pví brúin er pað sem eftir stendur pegar vegurinn er orðin að alfaraleið. Öllum er ljóst að brúin gerir peim kleift að fara yfir hana, en að öðru leyti er hún ekkert sérstök, aðeins pað meðal sem tilgangurinn helgar.

Pversögnin felst í pví að prátt fyrir brúargerðina vill gjáin ekki hverfa úr huga manna; hún er enn mikilvægasta landslagið á leiðinni og ekki að ástæðulausu. Auk pess getur brúin orðið léleg, verið of mjó eða bara ljót og í engu samræmi við hrikalegt landslagið sem undir er að líta. „Og af hverju er hún parna en ekki hérna,“ hugsa peir sem fjær búa. Brúin er í raun og veru alltaf ómögulegt vegna pess að hún sker sig úr og til að bæta gráu ofan á svart er oft einhver tollheimtumaður, brúarsmiðurinn sjálfur eða snjall fjárfestir, sem tekur gjald fyrir yfirferðina. Dannig getur brú sem opnaði nýja vegi orðið að kostnaðarsamri töf og leiðarlykkju í huga peirra sem vilja bara komast yfir gjána.

Brúin er líka pví marki brennd að vera einfalt mannvirki; í raun og veru aðeins planki yfir gjána. Sjálf hugmyndin er eins einföld og að ganga yfir byggða brúna. Bygging hennar krefst hins vegar meira hugvits en að leggja planka og pað sem meira er: efniviðurinn í hana virðist vera kominn yfir margar aðrar gjár. Ættunin er í pessari ritgerð að líta á nokkrar pessara gjáa og ekki síst smíði brúnna sem lyggja yfir pær.

2 Jón á Bagisá. Tímarit pýdenda. Norden er i orden. 2. tbl., desember 1995: 5-22. 


\section{Verkfærin}

Баð er góður siður í verklýsingum að byrja á að telja upp verkfærin og skýra tilgang peirra. Nú er engin skrá í pýðingafræðum tæmandi og reyndar koma verkfærin víða að og bera pví stundum með sér að peim hefur verið ætlað annað hlutverk í upphafi. Stundum reyna menn að nota sporjárn sem skrúfjárn og öfugt.

Stærsta vandamálið í verkfæralýsingunni snertir hins vegar strax einn grunnpunktinn 1 fræðum pýðinga, pann að ekki verður pýtt með orði fyrir orð, oft ekki einu sinni í geldum orðalistum. Samstofna orð í skyldum tungumálum hafa oft mismunandi merkingu, kannski nátengda ef svo má segja, en pó ekki hina sömu. „Waterfall“ á ensku merkir ekki pað sama og vatnsfall á íslensku. Frægt er dæmið um samanburð á orðum litrófsins par sem sum tungumál segja grænt lengur en önnur. Og „kinn“ er ekki á sama stað á Íslendingi og Pjóðverja pótt vænginn sé pað. Petta er kannski fremur spurning um hvar menn eiga að festa, ef yfirleitt, pað sem kallað er merking; í orðum, textum eða umhverfispáttum peirra (p.m.t. höfundum og viðtakendum).

\subsection{Jafngildi}

Detta hugtak má líkast til nota fyrir pað sem á pýsku er nefnt „Äquivalenz“ (t.d. Koller) og Nida og Taber kölluðu ,natural equivalent" 1 The Theory and Practice of Translation (11). Nida og Taber sem höfðu biblíupýðingar í huga voru par með ekkert langt frá skilningi Luthers á pýðingu sem hann skýrði í „,Sendbrief vom Dolmetschen“ par sem hann taldi eðlilegast að laga pýðinguna að tungumálinu eins og pað var í hans eigin málumhverfi (14-32). Eitt og sér er hugtakið hins vegar of einfalt til að verða að góðu gagni og hafa fræðimenn pví spunnið út frá pví fjölda práða í peirri von að flétta megi saman kenningar um pýðingarferlið. Kenningar pessar hafa spannað allt frá áherslu á form frumtextans til hagnýtingar marktextans í nútímasamfélagi; hinar fyrrnefndu standa frumtextanum nærri og vilja beygja pýðinguna undir aga hans, hinar síðarnefnðu snúast fremur um tilveru textans í p'vi samfélagi sem við honum tekur og beygja pýðinguna undir aga pess. Einhvers staðar parna á milli er kannski listamaðurinn sem telur sig hafa fundið hina einu réttu túlkun textans og pýðir hann mest eftir eigin höfði.

Einu gildir pó að hverjum pessara pátta menn hallast; með hugtakinu hættir mönnum til að skapa tvístefnubrú par sem pað er útilokað. Jafngildishugtakið á rætur að rekja til rökfræðinnar par sem gert er ráð fyrir að sannleiksgildi yrðinga sé hið sama beggja vegna jafngildismerkis og par með megi leiða hina fyrri aftur 
af hinni síðari (Stolze 93). Við pýðingu er hins vegar farinn svo miklu lengri vegur á milli yrðinganna að pær koma fyrir hvor í sínum heimi par sem forsendur eru allt aðrar, ekki aðeins á sviði tungumálsins heldur einnig menningarinnar í víðum skilningi pess orðs. Баð er útilokað аð finna frumtexta sína upprunalegu mynd með pví að pýða pýðingu til baka. Vandinn liggur kannski í pví að gjáin milli orða og innihalds peirra er brúuð með samhengi, ekki aðeins textans sjálfs, heldur líka pess umhverfis sem hann er lesinn í. Með pessu er ekki verið að fullyrða hvernig eigi að pýða, með prælslund eða pótta, heldur að pýðandinn breyti textanum með skilningi sínum og getu til að yrða hann upp á nýtt (sbr. Reiss/Vermeer 62). Dessi breyting er varanleg og óafturkræf.

par með er ekki sagt að hinn pýddi texti sé varanlegur, hver lesandi sér hvort eð er sinn texta, heldur felur athöfnin að pýða í sér slíka breytingu á formi og aðstæðum að ekki er lengur unnt að tala um jafngildi. Biblían er auðvitað gott dæmi um petta. Hún er mest pýddi texti sem fyrirfinnst og sá texti sem allir kynnast í pýðingu í einhverri mynd (Nida 11). Samt er pessi texti sífelldum breytingum undirorpinn prátt fyrir ótölulegar tilraunir til að nálgast hinn „heilaga frumtexta“. раð er einnig auðsætt að merking hans breytist með tíð og tíma og talandi dæmi um mismunandi skilning manna á honum eru sértrúarsöfnuðir mótmælenda. Mótmælendur lögðu gríðarlega áherslu á texta Biblíunnar, guðsorðið, sem sönnun pess að katólska kirkjan væri á villigötum. Textinn var par æðri mannlegum breyskleika og eini semskiptamöguleiki manna við Guð. En hvað gerðist? Menn gátu ómögulega orðið sammála um útleggingu textans og eru reyndar enn að finna nýjar. Pannig getur hugmyndafræði hvers tíma og ýmissa hópa léttilega mótað skilning á textum.

Dessu mætti andmæla á tvennum forsendum; trúarlegum og strúktúralískum. Dær síðarnefndu fyrst. Roman Jakobson orðaði pað svo í ritgerð sinni „On Linguistic Aspects of Translation“: „All cognitive experience and its classification is conveyable in any existing language“ (234). Petta ætti kannski að vera mottó hvers pýðanda, réttlæting á starfi hans og rothögg fyrir kenningar manna eins og Wilhelms von Humboldts sem í inngangi að pýðingu sinni á Agamemnoni Æskílosar fullyrti að „,ein Solches Gedicht ist, seiner eigenthümlichen Natur nach, und in einem noch viel andrem Sinn, als es sich überhaupt von allen Werken grosser Originalitaet sagen lässt, unübersetzbar“" (80).

Hvorug pessara fullyrðinga sannar né afsannar hugmyndina um jafngildi pýðingar og frumtexta (pótt segja megi að sú síðari sé tilraun til að sanna sjálfa sig); sú fyrri fullyrðir aðeins að tvær strúktúralískar andstæður, tvö tungumál, geti leyst nákvæmlega sama verkefni af hendi. Dessi leusn er ekki bundil pví að unnt sé að pýða frá p til q og síðan aftur til p, né heldur að q sé alveg jafngóður 
texti til að pýða yfir í be eins og p væri, aðeins að q geti sagt pað sama og p. Pessi röksemdafærsla gerir ráð fyrir að tungumálið og pað sem pað tjáir sé einungis skilvitlegt (cognitive) og að merkingu megi fastsetja í tíma og rúmi.Pýðing með pessum formerkjum leiðir til pess að menn ákveða merkingu fyrir tiltekið teikn (e. sign) í frummálinu og setja smana annað teikn í markmálinu sem segir pað sama (vonandi) og hið fyrra. Dau eru pó ekki jafngild par sem hið fyrra varð til óhað hinu síðara, en ekki öfugt. Pýðingin er heldur ekki rökrétt afleiðing frumtextans sme er á hinn bóginn algjörlega óháður henni.

Humboldt var hins vegar rómantískur hugsuður og skilningur hans á frumleika markast af snillingaguðfræði pess tíma sem upphóf skáldið og innblástur pess til slíkra hæða að pað hlaut að leiða til pess að menn litu á pýðingar bókmennta sem nýtúlkun á eigin tungumáli, samhliða peirri pversögn að verk snillings mætti aðeins meðhöndla sem helgan dóm. Býðingin hlýtur pví samkvæmt pessu allfat að vera annars flokks (fyrir hvern, spyrja pó peir sem frummálið ekki skilja), ef ekki helgispjöll og alls ekki jafngild frumtextanum.

\subsection{Textar}

Hér að framan hefur mikið verið talað um texta og pýðingar peirra án pess að skilgreina nákvæmlega hvað við er átt. Enda er pað ekki hægt. Textinn getur ekki verið bundinn við blaðið, hann er kominn annars staðar að og hann vill ekki bara liggja par pegjandi. Sé hann pýddur fer hann hugsanlega lengra og víðar en annars, en pá er hann kominn í nýjan búning pví hann sníður ekki fötin sín sjálfur hvert sem hann fer. Textinn er ekki túristi sem fer með hangikjötið sitt með sér, en hann fer með sjálfan sig og prófar kannski einkennilega ávexti par sem hann kemur.

Texta og pýðingar má pó flokka gróft pví um leið og flokkunin verður fín koma pversagnir innan textans í veg fyrir pað að gefa megi einhverjum flokknum lýsandi heiti. Раð er heldur engin tilviljun að flokkun beggja er nefnd í sömu andrá pví margir pýðingafræðingar (Reiss/Vermeer t.d.) byggja skilgreiningar sínar á flokkun texta. Hér er ekki um neitt nýtt að ræða fremur en fyrri daginn; prætubókarlistin til forna snerist að talsverðu leyti um flokkun texta (og Cicero er gjarnan nefndur til sögu sem fyrsti „pýðingafræðingurinn“). En eftir að Saussure greindi milli innihalds og málbeitingar, tungunnar sjálfrar o teiknakerfis hennar (langue) sem liggur að baki málinu og raunverulegri beitingu pess (parole), fóru menn að skoða tungumál með öðrum hætti en áður. 
Andstæðurnar, grundvöllur strúktúralískra málvísinda, skilgreina merkingu í gegnum tilveru eininga sem öðlast merkingu við раð аð vera ekki eins; pær nærast á samanburðinum hver við aðra: án gagnpóls er engin merking fyrir hendi. Til dæmis er erfitt að hugsa sér skilgreiningu á kynpáttum ef ekki væru til hvítir menn og blakkir, einungis gulir. Hin hreina og klára skipan andstæðnanna leiðir til pess að menn telja sig get rannsakað tungumálið eins og hlut, skýrt pað með hlutlausum hætti og hreinsað rannsóknir sínar af bjagandi hugmyndafræði. Gallinn er hins vegar sá að tungumál skoðandans er fyrir hlaðið merkingu og sú athöfn að tala um tungumálið gefur hlutnum merkingu, rétt eins og skilgreining hans á að útskýra eðli hans. Pannig er útskýringin alltaf að einhverju leyti fyrir fram gefin.

Í pessu samhengi ber að skilja útvíkkun merkingarhugtaksins í báðar áttir; frá merkingareiningunni teikn, samsettri úr peim páttum tungumálsins sem Saussure nefndi ,signifie“ eða hugtak og ,signifiant“ eða tjátak, til hinnar smæstu einingar sem breytt getur merkingu (fónem) og flóknari merkingarkerfa, t.a.m. texta og hugmyndafræði. Með pessari einföldun er ekki ætlað að skýra pessar kenningar, heldur aðeins að benda á að merkingin, pað sem pýða parf hverju sinni, er margfalt óhöndlanlegra fyrirbrigði en ætla mætti við fyrstu sýn, pegar menn líta til dæmis á orðið og merkingu pess. Fónemið getur breytt merkingu, en pað er ekki unnt að pýða (utan einstaka upphrópanir). Texta er unnt að pýða, en sá sem pýðir hann skilur hann kannski öðruvísi en einhver annar; hér hafa fyrirbrigði eins og hugmyndafræði og tími mikla pýðingu. Úr sér gengin hugmyndafræði getur skilið eftir sig orð og hugsanagang sem kemst á milli lesanda og texta sem saminn er áður en hugmyndakerfið náði hápunkti sínum, hvort sem pað var í orði og/eða verki.

Fyrir utan slík grundvallaatriði verður merkingin oft illhöndlanlegri pegar reynt er að tjá menningarsérkenni. Hlutverk peirra í texta getur verið mjög mismunandi, allt frá pví að vera hulutlaus staðreynd par sem verið er að lýsa einhverjum stað og stund, til pess að vísa eindregið á einhverja hugmyndafræði eða hóp. Vandamálið fyrir pýðandann getur orðið pað að hvort tveggja, hin hlutlausa lýsing, sem og hin hugmyndafræðilega vísun, geta umsnúist í pýðingunni. Lýsingin hlutlausa getur orðið „exótísk“ og spennandi, stúlkur í strápilsum fá allt í einu einhverja allt aðra merkingu en í umhverfi frumtextans. Vísunin hugmyndafræðilega getur hins vegar farið alveð fyrir ofan garð og neðan vegna pess að fyrirbrigðið finnst ekki í umhverfi marktextans. Einhver hópur getur t.d. haft tungutak sem í sjálfu sér verður vísun til stöðu hans í umhverfi frumtextans. Vandræðalegar yfirfæslur á „sambærilega“ hópa í umhverfi marktextans eða hrein staðfæring eru stundum prautalending að lokum, en pær eru engin trygging fyrir pví að „áhrifin“ séu hin sömu. 
Einmitt pess vegna má pýðandinn ekki gleyma viðtakendum textans. Hann og aðrir sem menningarumhverfi pekkja og skilja að einhverju leyti eiga kannski auðvelt með átta sig á tingangi pess að gefa tilteknum menningarsérkennum nýtt form í umhverfi marktextans. En pað er vitneskja sem pýðandinn og pekkjendur búa einir yfir; kaupandi pjónustunnar sér hins vegar kannski að pað er munur á frum- og marktexta og ályktar sem svo að pýðingin sé ófullnægjandi. Nærgætni gagnvart viðtakendum merkir að pýðandinn eigi hvorki að setja sig á háan hest og ,einfalda“ textann svo að „lýðurinn“ fái hann skilið, né heldur að hann eigi að pvinga viðtakendur til að fletta upp í orðabókum á stöðum sem viðtakendur frumtextans purfa pess ekki.

\subsubsection{TeXTatengsL}

Snúnara verður pað fyrir pýðandann pegar mikið er um textatengsl í frumtextanum (e. intertextuality); t.d. vísanir í „alkunna“ texta utan frumtextans. Slík tengsl er að finna í nánast öllum textaflokkum (p. Textsorte); enginn höfundur, auglýsandi, pólitíkus eða blaðamaður er svo grænn að eiga ekki uppsláttarbók með tilvitnunum. ๖að er ekki nóg að fletta upp í pýðingum Helga Hálfdanarsonar (að öðrum ógleymdum) pegar höfundur ensks texta slær um sig með Shakespeare pví pað er allsendis óvíst að viðtakendur pýdda texta átti sig á samhenginu hvert svo sem pað á að vera. Hér eru lausnir allt frá gæsalöppum til neðanmálsgreinar (í rituðum texta) mögulegar; allt annað en að pýða textann eins og hann kemur af skepnunni.

Textatengsl eru hins vegar flóknara fyrirbrigði en hreinar tilvitnanir í aðra texta. Ástráður Eysteinsson talar um „tengdatexta“ í ritgerð sinni „Mylluhjólinu“ og leggur par „áherslu á muninn á „föđurtexta“ áhrifarýninnar og peim mæðgum (stöðu tengdaforeldra) sem felast í textatengslum er lúta jafnframt að lesandanum - mismunandi lesendur geta séð ólíka tengdatexta í sama verki án pess að einn hafi réttar fyrir sér en einhver annar“ (78). Dessi áhersla á skilning og forpekkingu (p. Vorwissen/Weltwissen) lesandans undirstrikar að verkefni pýðandans felst ekki einungis í pví að pýða setningar yfir á markmálið heldur verður hann að kunna að meðtaka texta, skilja hvaða markmið tilteknir pættir innan textans hafa.

Sumir skilgreina pýðingar meira að segja sem textatengsl og kalla frumtextann fortexta (p. Prätext) og alla aðra texta sem upp úr honum eru unnir fylgitexta (p. Folgetext) (Schreiber 9). Dýðing er pannig ein gerð textatengsla, en fylgitextar geta verið af mörgum öðrum gerðum: satírur, útdrættir, leikgerðir 
o.s.frv. Meginatriðið felst í pví að textinn eigi sér einhverja fyrirmynd, eða vísi á einhverja fyrirmynd á einhverjum stað. Um leið er ljóst að pýðandinn getur ekki einfaldlega látið slíka vísun framhjá sér fara eins og ekkert sé. Petta litla atriði er í raun og veru stærra en ætla mætti í fyrstu pví að pað undirstrikar að textar eru ekki aðeins orð sem sögð voru og skrifuð heldur var peim ætlað að koma við eitthvað í lesendanum á einhvern sérstakan hátt. Yrðing frumtextans breytir pannig lesandanum að einhverju leyti (óháð pví hvort hann er sammála textanum eða ekki) og verkefni pýðandans er að átta sig á með hvaða meðölum peim tilgangi er náð og hvaða meðölum hann getur beitt í markmálinu til að ná sama tilgangi. Par með eru komnar fleiri forsendur til sögunnar en hinn svarthvíti frumtexti.

Dýðingafræðingarnir Katharina Reiss og Hans J. Vermeer hafa skilgreint texta sem tilboð um upplýsingar og segja verkefni pýðandans að gera viðtakendum í markmálinu sams konar tilboð með sínum pýdda texta (53-70). Đar sem pýðing feli alltaf í sér flutning á menningarsérkennum eða menningaraðlögum (p. kultureller Transfer) hljóti maður að skilgreina pýðingu textans pannig: „Die Dominante aller Translation is deren Zweck" (96).

Detta pýðir í raun og veru að pýðandinn eigi ekki að setjast niður og pýða setningu fyrir setningu eins og svo oft er gert. Баð er ekki punkturinn á milli setningana í frumtextanum sem skera á úr um skilin milli setningana í marktextanum, heldur á pýðandinn að gefa sömu upplýsingar og frumtextinn hefur að geyma með peim hætti sem eðlilegt er í markmálinu. Detta gerir líka pá kröfu til hans að hann hafi áttað sig á peim tilgangi sem textanum er ætlað að uppfylla (sé markmiðið með pýðingunni ekki hreinlega að breyta peim tilgangi, t.d. sögu fyrir fullorðna í sögu fyrir börn).

Slíkur skilningur á tilgangi frumtextans ásamt með skýrum markmiðum fyrir pýðinguna hlýtur að auðvelda pýðandanum að brjóta smærri vandamál til mergjar og forða honum frá pví að falla í gildrur frumtextans, fólgnar í orðaröð og öðrum mál- og menningarsérkennum hans, páttum sem enga merkingu hafa í markmálinu, nema vísvitandi sé verið að ögra sérkennum frummálsins.

\subsubsection{TeXtaflokkur og teXtager円 (b. TeXtTyp)}

Faðir pýðingafræðanna á pýskri tungu, Friedrich Schleiermacher (að Luther frátöldum), flokkaði pýðingar í upphafi nítjándu aldar í tvennt: 1) pýðingar fagurog fræðibókmennta og 2) túlkun á verslunarsamskiptum (39-40). Prátt fyrir að eitt og annað hafi breyst á peim tíma sem liðinn er virðist pankagangur margra í 
tengslum við pýðingar lítið breyttur. Бað eru til fagurbókmenntir og „,annað“. Dessi einfalda flokkun gengur ekki upp ef menn vilja nálgast texta og meta pá faglega, hvort sem pað er til að átta sig á hvernig er best að pýða pá eða hreinlega hvað á að fara fram á mikið fyrir verkið.

Eins og fyrr sagði, hlýtur slík flokkun alltaf að vera í grófara lagi, par sem ýmis sérkenni (p. Merkmale) einnar gerðar má kannski finna innan annarrar. Í kunnri bók sinni Texttyp und Übersetzungsmethode. Der Operative Text, byggði Katharina Reiss kenningar sínar á hinu svokallaða „Organon-módeli“ málvísindamannsins og strúktúralistans Karls Bühlers, sem m.a. var kunnur fyrir hlutdeild sína að „Prag-skólanum“ í málvísindum (eins og Jakobson). Kenning Bühlers, sem rætur á að rekja til Aristótelesar, er í sem fæstum orðum sú að teiknið hafi prjú höfuðeinkenni: a) lýsingu (p. Darstellung); b) tjáningu (p. Ausdruck); og c) ákall (p. Apell). Dessi einkenni eru leidd af grunnmarkmiðum teiknisins skv. Bühler: Symptom, Signal og Symbol. Dar sem ekki er unnt að pýða skilgreiningu teiknisins beint yfir í skilgreiningu textagerðarinnar flokkaði Reiss textana í 1) upplýsandi texta (p. informative T.): 2) expressífa texta (p. expressive T.); og 3) virkjandi (p. operative T.) (Reiss/Vermeer 204-216).

Hér sjá menn vitanlega strax að margir textar eru blöndur af pessu öllu saman, en pó fer ekki hjá pví að nefna megi marga texta til einnar gerðar að mestu leyti og pað sem vinnst við pað fyrir pýðandann er að hann getur skilgreint fyrir sjálfan sig hvaða aðferð kemur sér best og hvaða form er viðeigandi í markmálinu. Sé um að ræða upplýsandi textagerð eins og til að mynda notkunarleiðbeiningar með raftæki getur hann ákveðið að pýða í peim stíl sem er í samræmi við hefðir og venjur markmálsins.

Bókmenntatextar eru heldur ekki einungis expressífir í pessum skilningi; í peim eru oft (upp)lýsingar og virkjandi pættir og leikmunir rithöfundarins hafa ekki allir listrænan tilgang í sjálfum sér. Ritúal á borð við útför eða giftingu er til að mynda með algengustu viðburðum í bókmenntaverkum (î víðum skilningi pess orðs) og fastmótuð pula klerksins hefur ekki alltaf að geyma einhverja djúpa merkingu, en sé hún pýdd samkvæmt orðanna hljóðan getur hún fallið úr samhljómi við pað sem menn skynja sem „,venjulega“ útför eða giftingu. Til dæmis segja menn gjarnan við brúðkaupsaltarið á ensku „I do“ sem enginn heilvita íslenskur pýðandi pýðir með „ég vil““ eða „ég geri (pað)“.

pannig hlýtur pað að vera til bóta fyrir pýðandann að átta sig á peim markmiðum sem textinn hefur í heild og peim undirmarkmiðum sem hann parf að fást við á hverjum stað. Баð auðveldar honum að nálgast verkið eins og hann skilur pað og skila pví frá sér með peim hætti sem dómgreind hans segir honum 
að pað eigi að vera, pví enginn, hvorki hinn mesti listamaður, né hinn stîllausasti reglugerðarati, setur eitthvað inn í texta að ástæðulausu; vera kann að menn hafi ekki getu til að setja samana texta sómasamlega, en markmiðið er alltaf að skapa einhverja heild sem segir eitthvað í heild sinni. Sé textinn vísvitandi sundurlaus eða snubbóttur er pað undirstrikun pess að heildin sé ekki par sem hún á að vera. Sé hún pað ekki vegna pess að málnotandinn getur ekki betur, er eitthvað „að“ textanum, pað „vantar“ eitthvað í hann, hann segir ekkert af „viti“ (og lagfæring slíkra texta lendir oft á pýðendum). Engin setning textans er honum óviðkomandi og hvernig getur pá mönnum dottið í hug að textinn sjálfur í heild sinni geti verið setningum óviðkomandi?

\section{3 •ýðingafræði; heimspeki eða heimska?}

Margur atvinnupýðandinn hefur hrist höfuðið yfir „prugli“ pví sem pýðingafræðingar hafa látið frá sér fara, oft með athugasemd í pá veruna að „svona abstrakt pælingar komi engum að gagni““. Á pessu eru vitanlega margrar skýringar: í fyrsta lagi hafa menn í erli dagsins einfaldlega engan tíma til að standa í svona pælingum, í öðru lagi er oft verið að „segja pað sem allir heilvita menn gera“, í priðja lagi blundar kannski ótti við pað að vanmáttur og slæmir siðir verði öllum ljósir. Í fjórða lagi geta menn síðan borið fyrir sig að kenningar í pýðingafræðum séu ekki miklu langlífari en sumarblóm.

Fjölda kenninga og ákafan ágreining í pessum fræðum má eflaust rekja til pess hve bágræk tungumál eru. Algjör vanmáttur tölvutækninnar til að leysa svo einfalt vandamál eins og að pýða hefur fært mönnum heim sanninn um að tungumálið geymir pann flóknasta galdur sem mannskepnan hefur fundið upp á. Vissulega komast gríðarlega öflug tæki nálægt pví að umorða texta yfir á annað tungumál, en slíkir textar geta sjaldnast staðið undir pví að heita pýðingar; pað parf alltaf einhver að lesa textann yfir eins og hann væri skrifaður af manni sem fær flog annað veifið; allt í einu sprettur fram í textanum bull og vitleysa sem engum pýðanda hefði dottið í hug. Eina færa leiðin, enn sem komið er, felst í pví að fella frumtextana (oftast er talað um mjög sérhæfða, upplýsandi texta) undir tilteknar, gefnar ritvenjur sem eru pannig á færi tölvunnar að pýða. Sú lausn vekur hins vegar spurninguna hver á að ákveða slíkar venjur og hvort menn gera pað me tungumálapörum eða reyna að finna heildarlausn fyrir öll tungumál (sem vísast yrði engum til pægðar).

Vandinn sem allir pýðingafræðingar glíma hins vegar við er að skilgreina hvað sé unnt að flytja á milli tungumála, hvað megi/purfi að laga að peirri 
heimsmynd sem fyrir er og hvað ekki. Schleiermacher orðaði pað svo í ritgerð sinni „Methoden des Übersetzens“ að til væru aðeins tvær grundvallaraðferðir: „Entweder der Übersetzer läßt den Shcrifsteller möglichst in Ruhe, und bewegt den Leser ihm entgegen; oder er läßt den Leser möglichst in Ruhe und bewegt den Schriftsteller ihm entgegen.“ (47). Drátt fyrir að pessar grófu leiðbeiningar frá upphafi nítjándu aldar gangi einu skrefi lengra en margur heittrúarmaðurinn í faginu hefur komist enn pann dag í dag, eru pær langt frá pví að vera fullnægjandi skýring á pýðingarferlinu og peim aðferðum sem við pað er beitt. Kenningasmiðir reyna sífellt að komast yfir pennan vanda með nýjum heitum á tilfærslunni og vissulega komast peir áleiðis á mörgum tilvikum.

En hvað er pað pá sem menn pýða ef pað er ekkert eitt sem samt skal verða allt? Er pað kannski ímyndun að pað sé hægt? Hafði Humboldt rétt fyrir sér prátt fyrir pýðingu sína á Agamemnoni? Og hvað er býðing yfirleitt? Er hægt að skilgreina fyrirbrigðið? Dýðingafræði hafa enn ekki veitt endalegt svar og reyndar minna pau oftar á heimspekilegar vangaveltur en einfaldar leiðbeiningar um hvernig eigi að fara að pví að pýða; verkefnið virðist ámóta örðugt og að segja fólki hvernig pað eigi að lifa: allir vita hvernig á að fara að, en enginn getur pað lýtalaust, möguleikarnir virðast óendanlegir, en samt purfa menn að velja og pegar rökin prýtur eru hugmyndafræði og trúarbrögð oft seinasta hálmstráið.

\section{Tungumálið sem pýðing}

Tengsl pýddra texta við frumtexta minna oft á hina platónsku eftirlíkingu skáldskaparins af lífinu, eftirlíkingu eftirlíkingar sem Platón vildi brottræka gera úr fyrirmyndarríkinu (að minnsta kosti afurðir minni háttar spámanna) af pví hún getur aldrei uppfyllt pá kröfu sem hann gerir til frummyndanna, algildra viðfanga hugsunarinnar, hugtaka sem hrein eru af skoðunum (humyndafræði?) og teljast pannig sönn pekking, gagnstætt sýndarveruleikanum sem aðeins er skuggi á hellisvegg fanga skynjunarinnar einnar (sbr. Eyjólfur KJalar Emilsson, Inngangur að Ríkinu, 46-77). Líti menn svona á pýðingar er kannski ekki að furða að pær pyki alltaf lítilfjörlegar í samanburði við frumtextann hvað sem gæðum peirra og áhrifum að öðru leyti líður.

Aðrir líta svo á að hin besta af öllum mögulegum pýðingum sé aðeins hinn upprunalegi textinn á öðru tungumáli eins og t.d. Jakobson í áðurgreindri ritgerð par sem hann segir líka: „Languages differ essentially in what they must convey and not in what they may convey" (236). Hið ófrávíkjanlega skilyrði er aðein formgerðin, strúktúrinn, en merkingu hans má koma til skila með öðru móti, enda fullyrðir 
hann framar 1 textanum að „no grammatical device in the language translated into makes impossible a literal translation of the entire conceptual information contained in the original“ (235). Við petta er tvennt að athuga: Hér er í fyrsta lagi gert ráð fyrir að fjöldi grunnmerkinga strúktúrsins (ef ekki tungumálsins í heild) sé takmarkaður (skilgreindur) og hljóti par með að vera til í öðru tungumáli. Til að vega upp pessa takmörkun má segja að sköpunarkraftur tungumálsins hljóti alltaf að vera hinn sami i öllum tungumálum og par með gangi fullyrðingin upp, en hún skilur samt eftir pá spurningu hvort um pýðingu sé að ræða, eða hvort skilgreining manna á pýðingu sé einfaldlega röng. Í öðru lagi má spyrja hvað skilgreina megi sem „conceptual information“. Svo tekið sé dæmi af sonnettunni pá geymir formið hrátt til að mynda upplýsingar um innihaldið; pað er nánast undantekningarlaust ávarp skáldsins, oftast ástar- eða lofljóð til einhverrar persónu, oft með sjónarhornsbreytingu í níundu hendingu. Dessar upplýsingar eru fólgnar í forminu einu, eða hefðinni sem skapast hefur, en samspil peirra við innihaldið gerir koma til skila á sviði orða, málfræði og stíls. Einhvers staðar hljóta upplýsingar að fara forgörðum og menn verða að gera upp við sig hvort peir láta par við sitja eða bæta pað upp á öðrum stað. Og reyndar segir Jakobson undir lokin í rigerðinni að „poetry by definition is untranslatable“. (238)

Dýðing hlýtur pví alltaf að vera sambærileg við ,afmyndun“ skáldskaparins á veruleikanum, nema hún er einu prepi fjær og par af leiðandi enn verri en skáldskapurinn, svo ekki sé minnst á pýðingar býðinga. Niðurstaðan er eina ferðina enn að pýðing sé í raun og veru útilokuð.

Svo ályktar Jacques Derrida í ritgerðinni „Des Cours du Babel“, sem er nokkurs konar formáli að ritgerð um ritgerð Walters Benjamins „Die Aufgabe des Übersetzers“ (243). En Derrida tekur á pessu gamla vandamáli á nýstárlegan hátt; nákvæm greining á orðinu „Babel“ leiðir í ljós að pað er ópýðanlegt en samt ekki; merking pess er í fyrsta lagi borg guðs og í öðru lagi er pað sérnafn á borginni (og) turninum sem Guð kom í veg fyrir að lokið yrði við með pví að rugla tungumál íbúanna. Uppfrá pví purftu menn að „pjóða“ útlendar tungur til að skilja hverjir aðra, og petta sérnafn er pví tákn fyrir rugling eða ringulreið, ein hin pversagnarkennda athöfn fól pannig í ser að Guð fyrirskipaði pýðingar um leið og hann bannaði pær (249). „Translation then becomes necessary and impossible, [...]“ (s.st). Munurinn er sá að hin ósamræmanlega heild tungumálanna myndar grunninn; pau eru í reynd alltaf pýðing á veruleikanum og hvert á öðru. Dannig verða pýðingar skilgreindar sem grundvallarnauðsyn sem útilokað er uppfylla. 


\subsection{Er orðið guð eða guð orðið?}

Раð er kannski engin tilviljun að Fást, par sem hann situr fastur í svartholi sinnar eigin visku, skuli kalla fram Mefistófeles með pví að ætla sér að breyta upphafsorðum Jóhannesarguðspjalls. Orðið, nafnið, er fyrsta huglæga verkfæri mannsins, fyrsta prepið í turntröppunum og án pess væru hin óhugsandi. Nöfnin veita veruleikanum merkingu og gera mönnum pannig kleift að athafna sig í honum. Orðin hafa pannig oft hreina merkingu í hugum manna, merkingu sem er a priori beintengd hugsuninni og par með hreinni skynsemi. Fest 1 varanlegu formi og með í sér fólgna merkingu pá sem mönnum er heilögust af öllu öðlast orðin margfalda pýðingu, pau verða skýring á tilveru lesandans og réttlæting hennar um leið. Texti eins og Biblían skapar síðan andlegt umhverfi fyrir pá sem á hann trúa og pað skyldi pví engan furða að orðin í slíkum textum hafi í stundum verið mönnum eins heilög og líkneski dýrlings.

раð er líka tvennt sem pýðendur eru einkum gagnrýndir fyrir: að pýða orðin vitlaust og að pýða orðrétt. Að hluta til má rekja slíka gagnrýni til fjölmerkingar orða og að hluta peirrar viðbótarmerkingar sem frá viðtakandanum kemur. Bókstafstrúarmönnum í upprunalegustu merkingu pess orðs finnst pað eflaust vera orðhengilsháttur að tala um merkingargjöf viðtakanda orða, en pá hugsun má rökstyðja með tvennum hætti: Í fyrsta lagi standa orð alltaf fyrir eitthvað, pau eru aldrei hluturinn eða hugtakið sjálft, aðeins eftirlíking pess. Hugsunin og tjáningin sjálf skipta líka máli, en pað má segja að pað séu aðferðir til að koma viðbótarmerkingunni að án pess að breyta orðinu. Pessi eftirlíking kann að sýnast eins á yfirborðinu í öllum tilvikum, en notandi hennar hjalar hana ekki út í loftið heldur vill hann segja eitthvað við heiminn. Skoðun eða tjáningarpörf hans eru hvatinn að pví að verkfærinu er beitt. Í öðru lagi er pað staðreynd að tungumál breytast með tíðaranda og umhverfi og merking orða par með.

Helgin, sem yfir orðinu hvílir, verður samt sem áður aldrei af pví tekin að fullu og er pað af hinu góða. Hún veitir orðunum pað líf sem tjáningin parf til að eiga raunverulegt erindi við tilveru manna, erindi sem veitir pessari tilveru raunverulegan tilgang. Hjá Jóhannesi guðspjallamanni holdgervist petta erindi, hinn upprunalegi sannleikur Guðs, í Jesú; „,og orðið varð hold“ $(1,15)$ í íslenskri pýðingu frá 1991 sem líkast til hefur hina pröngu merkingu „holds“ frá Luther pótt textinn eigi að heita „ný pýðing úr frummálunum“. Holdið hefur hér víðari merkingu en pá eina að Guð hafi komið til jarðar í mannsmynd, allur hans sannleikur endurspeglaðist í öllu lífi, dauða og upprisu Krists, orðum hans og gerðum. Líkami Krists var einungis miðill Guðs, miðill sem náði tilgangi sínum með pví að deyja táknrænum dauða. 
Degar nánar er að gáð hefur Jóhannesguðspjall önnur markmið en hin guðspjöllin prjú, textinn undirstrikar hinn ,guðlega“ pátt Krists í gegnum boðskap hans, Drottins, og með pví að bera kraftaverkum hans vitni, kraftaverkum sem eru hin veraldlega sönnun gæsku og guðlegrar orku. Orðið og sannleikurinn eru eitt, einn boðskapur, sem öllum skal unnt að skilja í gegnum tákn sem í sjálfum sér eru ofar öllum skilningi. Allir peir textar sem við Jóhannes guðspjallamann eru kenndir bera einkenni hugmyndafræðingsins sem trúir og vill breiða út boðskapinn með pví sem hann veit öflugast af öllu, orðinu. Í guðspjalli sínu beitir Jóhannes verkfærum prætubókarlistarinnar og lofar viðtakendum orðsins eilífu lífi og upprisu holdsins (5 24-29) meðtaki peir orðið og geri að sínu.

Fyrir pýðendur er hins vegar mest um vert að brjóta heilann um hvernig Jóhannes og eftirritarar hans hafa mótað orðið og pýðingu pess í táknið, andstæður góðs og ills, guðs og manns, og prenndir hins guðlega sannleika sem sífellt koma fram í nýjum myndum í textunum. Meðan gott og illt fá aldrei saman komið er hamrað á að pa sé „andinn, sem lífgar, holdið gagn[i] ekkert; orðin, sem eg [Jesús] hefi talað við yður, eru andi og eru líf.“ (6, 63-64) Andinn í orðinu tengir saman mannslífið og guðsríki og er par með heilagur, hinn heilagi andi. Skilyrðin sem pessum skilningi fylgja eru vitanlega engin smásmíði. Jóhannes orðar pau sjálfur skýrt í lokaorðum opinberunar sinnar og par með tveimur af síðustu versum Biblíunnar: „Eg votta fyrir hverjum peim manni, sem heyrir spádómsorð pessarar bókar, að leggi nokkur við pau, mun Guð á hann leggja pær plágur, sem um er ritað í pessari bók. Og taki nokkur burt nokkuð af orðum spádómsbókar pessarar, pá mun Guð taka hlut hans í tré lífsins og í borginni helgu, sem um er ritað í pessari bók.“ (22, 18-19)

\subsection{Eða er orðið list?}

Degar Walter Benjamin ritaði um „Verkefni pýðandans“ fyrr á pessari öld hefur hann kannski haft fyrirmæli Jóhannesar guðspjallamanns í huga. Benjamin kemst í lokin að peirri niðurstöðu að „die Interlinearversion des heiligen Textes is das Urbild oder Ideal aller Übersetzung“ (169). Dessi ályktun kemur nokkuð á óvar pegar hugsað er til pess að ritgerðin kom út eftir að verk Saussures Cours de linguistique générale hafði gefið tóninn fyrir hin módernísku málvísindi, strúktúralismann.

Dó er auðsætt að Benjamin hefur lesið Saussure og sumar af niðurstöðum hans stangast engan veginn á við pað sem strúktúralistar geta sætt sig við. Rök hans fyrir pví að tungumál (eða textar öllu heldur) sé pýðanleg „,besteht darin, daß 
die Sprachen einander nicht fremd, sondern in dem verwandt sind, was sie sagen wollen" (159). Eins og fyrr sagði er petta í raun og veru kjarni pess sem Jakobson hafði um pýðingar að segja í ritgerðinni frægu; öll tungumál hafa sama tilgang, munurinn er aðeins sá hvernig menn segja sömu hlutina.

En par skilur leiðir hjá Benjamin og strúktúralistum. Hann segir að vísu í upphafi að „Übersetzung [...] eine Form [sei]“, en pað er ekki form strúktúralista, „formgerðarmanna“, heldur vísar pað miklu fremur til Aristótelesar og kannski postulans Jóhannesar par sem formið er í raun og veru innihald hlutanna, eðli peirra óháð ytri birtingarmyndum. Par með veitir hann pýðingunni frelsi frá pví að vera einhver annars flokks eftirmynd um leið og hann gerir pað skilyrði að hún sé nánast orð fyrir orð höfð eftir frumtextanum. Petta er auðvitað pversögn, en önnur pversögn er að segja að „conceptual information“ sé alltaf yfirfæranleg á milli mála. Jakobson talar um „equivalence in difference“ (233) án pess að skilgreina nánar hvernig megi brúa pann mun, eða eins og Derrida orðar pað í fyrrgreindri ritgerð sinni: „,...] Jakobson does not translate; he repeats the same word: ,interlingual translatio or translation proper“" (252).

Benjamin gengur út frá peim meginpunkti að listaverkið sé ekki til pess gert að falla viðtakandanum í geð heldur sé pað algjörlega sjálfstætt í eðli sínu: „Denn kein Gedicht gild dem Leser, kein Bild dem Beschauer, keine Symphonie der Hörerschaft" (156). Y firfærða á listina sjáum við helgi orðsins sem fær hér guðlega merkingu í öðrum skilningi en hinum rómantíska, sem setti listamanninn sjálfan í miðju sem nánast guðlegan skapara pessarar listar, en pað er einungis í gegnum listina sem menn ná sambandi við guð, ekki listamennina. Peir eru aðeins pýðendur.

Nú skyldu menn ekki ætla að Benjamin hafi verið að rita um guðfræðileg efni, síður en svo, ritgerðin snýst fyrst og fremst um verkefni pýðandans, hvað pýða eigi og um leið hvernig. Forsendur hans felast ekki í pví að finna hvað höfundur frumtextans „meinar“ og ekki heldir í pví að koma „meiningu“ frumtextans til skila heldur eðli hans og petta eðli er einnig að finna í frummálinu. Detta er öðruvísi krafa um tryggð en maður á að venjast og liggur ef til vill í pví að Benjamin lítur ekki á tungumálin sem formrænar og asðkildar einingar heldur lifandi hluta af stærra tungumáli (165). Samtímis hlýtur spurningin um hvort pýðing sé möguleg að koma fram af auknum krafti.

En Benjamin finnur leið út úr ógöngunum með pví að eita til Jóhannesar guðspjallamanns, „í upphafi var orðið“, og hafna peirri hugmynd að ekki megi vera „pýðingabragð“ af pýðingunnii: „Die wahre Übersetzung is durchscheinend, sie verdeckt nicht das Original, steht ihm nicht im Licht, sondern läßt die reine Sprache, wie verstärkt durch ihr eigenes Mediu, nur um so voller aufs Original 
fallen“ (166). Dyngstu rökin fyrir pessu eru ekki einungis pau að flestar pýðingar sem verulegu máli skipta ýti við markmálinu innan frá heldur fullyrðir hann að „es bleibt in aller Sprache und ihren Gebilden außer dem Mitteilbaren ein Nicht-Mitteilbares, ein, je nach dem Zusammenhang, in dem es angetroffen wird, Symbolisierendes oder Symbolisiertes“ (166).

Táknandinn og hið táknaða minna á grunpætti teiknisins hjá Saussure, en Benjamin bætir við pað briðju víddinni, eða kjarna, og gerir að einni heild. Hið príeina teikn leitt af andstæðum; (afmarkaður) tími og (ótakmörkuð) eilífð eru hugtök sem fá merkingu hvort frá öðru, rétt eins og gott og illt, annað er óhugsandi án hins. Eðli listarinnar er kjarninn í hugsun Benjamins og kjarninn í hinu hreina tungumáli; petta eðli kemur fram í táknandanum og hinu táknaða samtímis, táknandinn er birtingarmyndin og hið táknaða er tilraun til að mynda kjarnann í verðandi tjáningarinnar. Sú staðreynd að kjarninn er bundinn táknanda sínum bindur einnig við hann tunga byrði annarlegrar merkingar, utanaðkomandi áhrifa. „Von diesem sie zu entbinden, das Symbolisierende zum Symbolisierten selbst zu machen, die reine Sprache gestaltet in der Sprachbewegung zurückzugewinnen, ist das gewaltige und einzige Vermögen der Übersetzung“ (167).

\section{Tilbúningur textans}

Orð eru ekki orð, heldur landslag í veröld sem kalla má texta. Lestur textans er tilraun til að lifa í pessari veröld textans. Hvort menn verða úti á ferð sinni 1 pessari veröld er undir ýmsu komið, en fyrst og fremst málkunnáttu og víðsýni peirra sem textann mynda og meðtaka. Petta er ekki nauðsynlega bundið við fagra eða upphafna bókmenntatexta, trúartexta. Fögur sonnetta getur veitt lesanda margfalt meiri andlega fullnægingu með miklu minni fyrirhöfn en fóknar leiðbeiningar með myndbandstæki.

En hver er pá munurinn á frumtexta og pýddum texta? Og hvað er eiginlega frumtexti? Svörin við pessum spurningum eru ekki eins einföld og ætla mætti. Margir greina á milli pýðinga innan máls og milli mála eins og t.d. Jakobson sem greindi pær í prennt:

1) Intralingual translation or rewording is an interpretation of verbal signs by means of other signs in the same language.

2) Interlingual translation or translation proper is an interpretation of verbal signs by means of some other language. 
3) Intersemiotic translation or transmutation is an interpretation of verbal signs by means of signs of nonverbal sign systems. (233)

Dessar víðfrægu skilgreiningar í heimi pýðingafræða eru pó fremur opnar pegar nánar er að gáð. Sú fyrsta getur átt við hvers kyns úrvinnslu frum- eða fortexta, lekgerð, útdrátt eða hreinlega uppritun handrits fyrir tíma prenttækninnar. Mismunandi útgáfur margra handrita sem eiga að heita „uppritanir“ sýna að slík vinna gat farið eftir ýmsu, efnahag og hugmyndafræði svo dæmi séu tekin. Besta íslenska dæmið um innanmálspýðingu er kannski Gerpla Halldórs Laxness par sem hann endurnýjar hugmyndafræði Fóstbræðra sögu, ekki pá sem hugsanlegur höfundur hennar lagði í hana, heldur miklu fremur hinn rómantíska skilning nítjándu aldar pegar hetjur riðu um héruð.

Skilgreining númer tvö er ekki einungis endurtekning eins og Derrida fullyrðir pví pað er lítið lykilorð fólgið í henni, nefnilega „interpretation“. Um leið blasir pversögnin í hinum strúktúralísku rökum Jakobsons við pví hér hlýtur hinn einstaklingsbundni páttur pýðingarinnar að skipta töluverðu máli. Dessi túlkun í tilteknu umhverfi rúms og tíma hefur úrslitaáhrif á hinn pýdda texta, pví sé gengið út frá pví að frumtextinn sé óbreytanlegur, skýrir petta hina óendanlegu möguleika á nýjum pýðingum texta. Textinn verður alltaf til að nýju við pýðingu og reyndar má færa rök fyrir pví að meira að segja ný útgáfa prentaðs texta sé aldrei hin sama og hinar fyrri, eða ætla menn ekki að pað sé töluverður munur á peim texta sem „smjörlíkissalinn“ gaf út fyrir Halldór Laxness á priðja áratug pessarar aldar og peim sem nýstudentinn fær í hendur á peim tíunda? Umbúðirnar einar og forpekkingin um líf textans og höfundar hans gerir hann að öðrum texta en á sínum tíma.

Frumtextinn og gríðarlega náið samband hans við höfundinn getur hins vegar stundum verið villandi, ekki af pví höfundurinn og líf hans skipti ekki máli eða sá texti sem fyrir liggur sé einungis leir sem móta megi að vild, heldur vegna pess að hugmyndir manna um hvort tveggja eru oft fyrir fram mótaðar og hafa áhrif á túlkun textans. Auk pess eru oft deildar meiningar um pað hver höfundurinn var og hvað han vildi í raun og veru segja. Fornir textar eru auðvitað gott dæmi um petta. Textar Aristótelesar, Biblíuhöfunda, Snorra Sturlusonar auk fjölda annarrra eru ekki til frá peirra eigin hendi. Oft er mörg hundruð ára munur í tíma ef ekki yfir púsund ár (Aristóteles) frá ritun frumtexta til elsta varðveitts handrits og engum heilvita manni ætti að detta í hug að pessir textar séu orð fyrir orð rétt eftir hafðir. Fræðimenn síðari tíma hafa síðan komið sér niður á hina „réttu“ útgáfu textanna, en pessi útgáfa er meira að segja á „frummáli,, peirra 
ekkert annað en innanmálspýðing byggð á vísindalegri túlkun peirra á empírískum gögnum. Afurð vísindanna.

\subsection{Lestur er túlkun}

Túlkun texta hefst með lestri peirra eða annarri meðtöku og getur gengið svo langt að menn framkvæma eitthvað af völdum peirrar túlkunar. Lesandinn er að vissu leyti í svipuðum sporum og höfundurinn meðan hann skrifar textann. Sköpunarferli lesandans felst í pví að hann reynir að skapa sér mynd af textanum í eigin höfði, reynir að fella hann að eigin hugmyndafræði, reynir að skilja hann með pví að átta sig á hvert textinn vill fara með hann. Ögri textinn hugmyndafræði lesandans verður hann að hafn textanum, a.m.k. að hluta til, eða breyta viðhorfum sínum til að koma til móts við hann.

Merking textans er trauðla bundin við hann hráan, í honum sjálfum. Merkingu sína öðlast hann fyrst pegar hann hefur verið meðtekinn í einhverju formi og hann hefur áhrif pegar menn fara að tala um hann og jafnvel breyta hugsun sinni og hegðan vegna hans. Slík áhrif hafa einstakir textar vitanlega sjaldnast; oftar eru peir hluti af stærra textakerfi innan hugmyndakerfis sem engan veginn er rökrétt heild, en markmið pess og dragbítar endurspeglast í textum sem ritaðir eru á hverjum tíma (sbr. Lefevere 11-40). Andstætt textakerfum verða menn hins vegar að meðtaka textaeinstaklingana í heild til að skilja pá sem einstaklinga. Petta er best að skýra með dæmi: Biblían er textakerfi sem fæstir menn hafa lesið í heild sinni en hefur hins vegar hugmyndafræðileg áhrif langt út fyrir pá staðreynd í hugmyndakerfi kristinna manna.

Eini sannanlega óskiljanlegi textinn er hinn algjörlega ólesni texti, týndur í algleymi. Hann er pað sama og hinn óskrifaði texti. En um leið og textinn er lesinn öðlast hann merkingu, oft langt út fyrir hinn prönga hring raunverulegra lesenda. Đað er merkinging sem veitir textanum líf, hún er líf hans eins og tungumálsins og hún heldur áfram að lifa svo lengi sem textinn er lesinn. Pess vegna má taka undir pað sem Guðbergur Bergsson sagði í ritgerð sinni „Skáldsagnahöfundurinn og textinn. 'Óttinn’ við textann“: „Баð að geta heillað huga annarra til að túlka, leggja merkingu í og skilgreina, skiptir líf skáldverks meira máli en að vita hvað rak höfundinn til að hrinda pví frá sér“" (51). Rétt áður hafði Guðbergur sagt að skáldverkið væri „tvífari [skáldsagnahöfundarins] í orðum, tungl sem piggur birtu frá tilverusólinni í alheimi hans (s.st.) og par með nátengt skáldsagnahöfundinum sem persónu.

Kannski skrifa menn til að halda tilteknum persónum á lífi, höfundinum eða öðrum (sbr. sonnettur Shakespeares sem reyndar halda nafni hans sjálfs betur 
á lofti en persónanna sem hann vildi mæra), kannski lesa menn skáldskap til að kynnast pessari persónu (eða persónum) og sé verkið gott getur farið svo að menn kynnist annarri betur, sjálfum sér, og tel ég pað vera hinn raunverulega lestur; pá fyrst hefur lesandinn skilið textann til fullnustu og samsamast honum að einhverju leyti. Pessi samsömun er nauðsynleg fyrir pann sem pýða vill skáldverk svo frambærilet sé og hún auðveldar vinnuna pví hún gefur af sér pá vissu að býðandinn get sagt með sínum orðum раð sem hann skilur.

\subsection{Svik að lokum?}

Gömul tugga á ítölsku, orðaleikur, gerir pví skóna að pýðandinn sé svikari við höfundinn, „traduttore, traditore“, og vilji menn færa myndhverf rök má segja að pað séu kannski örlög pýðandans að purfa að vera Júdas og svíkja höfundinn með kossi, og segja síðan pýðandanum til málsbóta að án hans, eins og Júdasar, væri verkið aldrei fullkomnað.

Detta er hins vegar rangt. Svik pýðanda við höfundinn geta aðeins komið fram í pví hvernig hann vinnur pýðinguna og pá svíkur hann sína eigin lesendur um leið. Höfundurinn og pýðandinn purfa að koma saman í einhverjum snertipunkti túlkunarinnar, snertipunkti sem endalaust má skilgreina upp á nýtt. Dað er pýðandans að leita að pessum punkti með allri peirri kunnáttu og hjálpartækjum sem hann hefur (mögulega) undir höndum og geri hann pað má segja að hann hafi sýnt höfundinum, og lesendum, nægilega tryggð til að túlka textann rétt í pað skiptið.

\section{Heimildir}

Ástráður Eysteinsson. „Mylluhjólið. Um lestur og testatengsl.“ Timarit Máls og menningar 4 (1993): 73-85.

Benjamin, Walter. „Die Aufgabe des Übersetzers.“ Í Störig, 156-159.

Biblia, pað er heilög ritning. Ný pýðing úr frummálunum. London og Reykjavík: British and Foreign Bible Society, 1919.

Die Bibel, nach der Übersetzung Martin Luthers. Stuttgart: Deutsche Bibelgesellschaft, 1985.

Derrida, Jacques. „Des Tours de Babel.“ A Derrida Reader. Between the Blinds. Ritstj. og skýr. Peggy Kamuf. Býð. Joseph F. Graham. New York o.v.: Harvester and Wheatsheaf, 1991, 244-253.

Eyjólfur Kjalar Emilsson. Inngangur. Í Ríki Platóns, 9-77. Reykjavík: Hið íslenska bókmenntafélag, 1991. 
Guðbergur Bergsson. „Skáldsagnahöfundurinn og textinn. 'Óttinn' við textann.“ Tímarit Máls og menningar 1 (1993): 51-61.

Humboldt, Wilhelm von. „Einleitung zu Agamemnon.“ Í Störig, 71-96.

Jakobson, Roman. „On Linguistic Aspects of Translation.“ On Translation. Ritstj. Reuben A. Brower. 2. útg. óbr. (1959). New York: Oxford University Press/Galaxy, 1966, 232-239.

Koller, Werner. Einführung in die Übersetzungswissenschaft. 4. útg. yfirf. (1979). Heildelberg og Wiesbaden: Quelle und Meyer, 1992.

Lefevere, André. Translation, Rewriting and the Manipulation of Literary Fame. Ritr. Translation Studies. London og New York: Routledge, 1992.

Luther, Martin. „Sendbrief vom Dometschen.“ Í Störig, 14-32.

Platón. Rikið. Dýð. Eyjólfur Kjalar Emilsson og Kristján Árnason. Ritr. Lærdómsrit bókmenntafélagsins. Reykjavík: Hið íslenska bókmenntafélag, 1991.

Reiss, Katharina og Hans J. Vermeer. Grundlegung einer allgemeinen Traslationstheorie. 4. útg. óbr. (1984). Tübingen: Niemeyer, 1991.

Schreiber, Michael. Übersetzung und Bearbeitung. Zur Differenzierung und Abgrenzung der Übersetzungsbegriffs. Tübingen: Narr, 1993.

Schleiermachr, Friedrich. „Ueber die verschiedenen Methoden des Übersetzens. “ Í Störig, 38-70.

Stolze, Radegundis. Übersetzungstheorien. Eine Einführung. Ritr. Narr Studienbücher. Tübingen: Narr, 1994.

Störig, Hans Joachim. Das Problem des Übersetzens. Ritstj. Hans Joachim Störig. Ritr. Wege der Forschung, 8. b. Darmstadt: Wissensch. Buchgest., 1963. 


\section{Tradução, teorização, traição. Ensaio sobre estudos de tradução ${ }^{3}$}

Gauti Kristmannsson

Tradução do islandês:

Luciano Dutra

Der Autor bat den Mund zu balten, wenn sein Werk den Mund auftut. ${ }^{4}$

Friedrich Nietzsche

\section{Introdução}

A tradução implica comportamentos contraditórios. Do verbo à ação, e logo novamente ao verbo, há um percurso longo e traiçoeiro, de difícil transposição, em especial pela simples razão de que só raramente é possível olhar para trás, na esperança de vislumbrar o caminho de volta. É um trajeto ao longo do qual, em dado momento, surgirá um abismo sobre o qual haveremos de estender uma ponte se quisermos transpô-lo. Esta construção de pontes constitui aquilo que a maioria das pessoas chama de tradução. Quanto à ponte, é a única coisa que permanece visível a partir do momento em que o caminho se torna transitável, já que ninguém negará que ela é o que torna possível transpor aquele obstáculo. De resto, ela não parecerá nada especial, mas apenas um meio que os fins justificam.

O paradoxo reside aí no fato de que, apesar de a ponte ter sido construída, não conseguimos desviar a atenção do abismo por ela transposto. E ele, o abismo,

3 Tradução integral do artigo publicado originalmente na revista sobre tradução Jón á Bagisá - tímarit pýdenda, vol. 2/1995, em Seltjarnarnes, Islândia, pela editora Ormstunga.

4 "O autor tem de calar a boca, quando sua obra fala" (Friedrich Nietzsche. Humano, demasiado bumano. Vol. 2. Trad., not. e posf. Paulo César de Souza. São Paulo: Cia. das Letras, 2008). 
continua sendo encarado, não sem razão, como o elemento paisagístico mais relevante de todo o percurso percorrido. Além disso, é possível que a ponte resulte precária, demasiado estreita ou simplesmente feia e de forma alguma à altura da impressionante paisagem que dela se descortina. "Mas por que ela foi feita lá, e não aqui?” - perguntar-se-ão aqueles que vivem longe dela. Por ser tão ostensiva, a ponte será sempre, de fato, uma impossibilidade. E para colocar ainda mais lenha na fogueira, não raro haverá um cobrador de pedágio - o próprio construtor da ponte, ou talvez algum investidor esperto - a recolher tarifa dos que fazem o percurso. E assim a mesma ponte que viabilizou um novo trajeto possivelmente se tornará um caro empecilho ou um impasse para aqueles que desejam tão somente transpor um abismo.

Uma ponte dá, ademais, a impressão de ser um construto bastante simples com efeito, nada além de uma tábua sobre um abismo. A ideia, em si, é tão singela quanto percorrer uma ponte já construída. Porém, a sua construção requer mais do que o ingênuo ato de estender uma tábua. Mas o pior é que o material de que ela é feita parece rigorosamente o mesmo utilizado para transpor outros abismos.

O objetivo deste ensaio é observar alguns destes abismos, bem como a construção das pontes que sobre eles se estendem.

\section{As ferramentas}

É de boa praxe abrir um memorial descritivo enumerando o ferramental a ser utilizado, bem como a função de cada ferramenta. A teoria da tradução, porém, não oferece nenhuma lista exaustiva neste tocante, já que as ferramentas traducionais são as mais variadas possíveis, algumas das quais se prestam afinal a usos de início insuspeitados - alguém poderá de vez em quando ver-se tentado a utilizar um formão em lugar de uma chave de fenda, ou vice-versa.

O maior percalço em se fazer, neste caso, um memorial descritivo diz respeito a um dos pontos elementares da teoria da tradução - o truísmo de que não é possível traduzir palavra por palavra, nem mesmo quando se trata p. ex. de um inocente glossário. Mesmo nos idiomas intimamente relacionados, palavras derivadas de um étimo comum não raro apresentam significados divergentes, muitas vezes ocupando campos semânticos bastante próximos mas não exatamente idênticos. Como exemplo, a palavra inglesa waterfall ("queda-d'água") não significa o mesmo que vatnsfall ("rio, arroio") em islandês. Um exemplo clássico é o estudo comparativo das cores, no qual se verifica que o que certos idiomas chamam de verde é já uma cor diferente noutros idiomas. Da mesma forma, kinn 
não descreve a mesma parte do corpo humano em islandês ("bochecha") e em alemão ("queixo"), ainda que vangi/Wange signifiquem o mesmo em ambos idiomas ("bochecha"). Talvez esteja em jogo o lugar em que os indivíduos penduram, via de regra, aquilo que se convencionou chamar sentido: nas palavras, nos textos ou nos entes pragmáticos (p. ex. o emissor ou o receptor) de um ato comunicativo?

\subsection{Equivalência}

Este conceito pode ser considerado, para todos os efeitos, como similar àquilo que em alemão é denominado Äquivalen $\varkappa^{5}$, ou àquilo que Nida e Taber chamam de "equivalente natural" em The Theory and Practice of Translation". Tendo em mente a tradução bíblica, estes autores não andaram lá muito longe da visão de Lutero sobre a tradução, conforme sua elaboração na "Carta aberta do doutor Martinho Lutero a respeito da tradução e da intercessão dos santos" ou na "Carta aberta sobre a tradução". Lutero julgou que o mais razoável seria modular a tradução ao idioma tal qual ele se apresentava no ambiente linguístico de seu tempo ${ }^{7}$. Mas este conceito, por si só, é simplificado demais para propiciar um bom aproveitamento, e os teóricos têm esticado seu sentido em várias direções, na vã esperança de conciliar as diferentes doutrinas a respeito do processo traducional, que abrangem desde a ênfase nas formas apresentadas pelo texto original até o foco na maximização do texto de chegada na sociedade contemporânea. A primeira destas vertentes toma mais para si as dores do texto original e pugna por submeter o texto de chegada aos interesses daquele. Já a segunda escola preocupa-se prioritariamente com a existência do texto no âmbito da sociedade para o qual ele é transposto e também não hesita em colocar a tradução a serviço desta visão. Em algum ponto intermediário entre ambas correntes, quiçá encontra-se o artista que julga haver encontrado a única interpretação correta do original sobre o qual se debruça, o qual traduz com base em seus próprios parâmetros mentais.

Porém, uma coisa é certa: este conceito fez com que os partidários de ambas vertentes desistissem, por inviável, de construir pontes de duas mãos. O conceito de equivalência remonta à lógica, a qual pressupõe que o valor lógico das proposições é idêntico de ambos os lados da equação, podendo-se, desta forma, deduzir

5 Cf. Koller.

6 Nida e Taber, p. 11. [Obra ainda sem tradução em português. Vide bibliografia para traduções em castelhano.]

7 Lutero, p. 14-32. [Vide bibliografia para traduções em português da obra.] 
a primeira a partir da segunda ${ }^{8}$. Quando se trata de traduzir, porém, a distância percorrida entre duas preposições é tão longa que elas se colocam cada qual em seu próprio mundo, cujos pressupostos são totalmente distintos, não apenas em termos linguísticos mas também em termos culturais, no sentido mais abrangente possível. Daí a inviabilidade de recuperar a forma original do texto de partida através do processo de retrotradução. O problema talvez resida no fato de que o abismo existente entre as palavras e seus conteúdos é transposto com o recurso ao contexto - e não apenas ao contexto intratextual, mas também ao contexto da enunciação. A ideia aqui não é determinar qual seria a melhor estratégia de tradução a ser adotada - o servilismo ou a petulância - mas sim afirmar que o tradutor modifica o texto a partir de sua interpretação do original e de sua capacidade de enunciá-lo outra vez . Esta modificação é a um só tempo duradoura e irreversível.

Isso não quer dizer que o texto traduzido seja duradouro - já que cada leitor opera, de qualquer forma, a sua própria leitura -, mas que o ato traducional em si carreia tamanha transformação, tanto nas formas quanto no contexto, que já não é mais possível falar em equivalência. A Bíblia é obviamente um bom exemplo neste sentido. Trata-se do texto mais traduzido de que se tem conhecimento, o texto que nos é familiar a todos, em alguma(s) de suas versões ${ }^{10}$. Por outro lado, ele é objeto de constantes alterações, a despeito de todas as inacreditáveis tentativas de se chegar ao "sagrado original". É evidente, da mesma forma, que o seu sentido vem mudando com o passar do tempo, sendo um exemplo eloquente das diferentes interpretações a ele atribuídas a existência de diversas seitas protestantes. Os protestantes atribuem enorme importância aos textos bíblicos, aos evangelhos, como forma de evidenciar que a igreja católica tomara a direção equivocada. O texto era para eles uma sofisticada demonstração da precariedade do homem e ao mesmo tempo a única forma de comunicação entre o humano e o divino. E qual foi o resultado? Os homens têm sido incapazes de chegar a um acordo quanto à exegese dos textos e continuam encontrando sempre novas interpretações. Desta forma, as ideologias reinantes em cada época e no seio dos mais diversos agrupamentos vêm inexoravelmente influenciando a interpretação daqueles textos.

Poderíamos refutar esta afirmação com base em dois aspectos: o aspecto religioso e o aspecto estrutural. Comecemos por este último. Roman Jakobson afirmou em seu ensaio "Aspectos linguísticos da tradução": "Toda experiência

\footnotetext{
8 Stolze, p. 93.

9 Reiss e Vermeer, p. 62.

10 Nida, p. 11.
} 
cognitiva pode ser traduzida e classificada em qualquer língua existente" ${ }^{\prime 1}$. Esse talvez devesse ser o lema de todo o tradutor, a justificação de seu ofício e um nocaute às teorias de autores como Wilhelm de Humboldt, que, na introdução à sua tradução do Agamenão de Ésquilo, sustentava que “[...] um poema desta monta, haja vista a sua natureza mesma, é intraduzível, em sentido ainda mais próprio do que quando afirmamos que toda obra de grande originalidade o é"12.

Porém, nenhuma destas asserções tem o condão de corroborar nem de refutar a noção de equivalência entre a tradução e o original, ainda que a segunda possa ser vista como uma tentativa de autovalidação. Já a primeira afirma somente o fato de duas estruturas em oposição - dois idiomas, no caso - serem capazes de desincumbir-se de uma mesma tarefa específica. Mas esta solução não implica a possibilidade de se traduzir de $p$ para $q$, e a seguir ao revés, nem tampouco que o resultado $q$ venha a ser bom o suficiente para justificar sua tradução para $b$ como sucedâneo do original em $p$. Ele apenas demonstra que $q$ é capaz de enunciar o mesmo que $p$. Essa argumentação pressupõe que um idioma e aquilo que ele manifesta seja de natureza exclusivamente cognitiva, tornando possível a sua apreensão no tempo e no espaço. Traduzir com este pressuposto em vista implica selecionar um sentido para determinado signo do idioma de partida e justapor um signo no idioma de chegada que - oxalá! - diga o mesmo que aquele primeiro signo. Porém, eles não são propriamente equivalentes, uma vez que o signo primordial foi gerado independentemente de seu sucedâneo, enquanto o mesmo não pode ser dito em relação ao segundo. Além disso, a tradução não é uma consequência necessária de um original, sendo este, por sua vez, absolutamente independente de sua tradução.

Humboldt é, de toda forma, um representante do romantismo, e sua opinião a respeito da originalidade é fruto da entronização da genialidade que é uma marca de sua época: o autor e a inspiração autoral foram alçados a um patamar tão elevado que qualquer concepção sobre a tradução só poderia ser a de uma reinterpretação do original numa outra língua, ao lado do paradoxo segundo o qual a obra de um gênio deveria simplesmente ser encarada como um juízo sagrado. A tradução, segundo esta doutrina, só poderia ser considerada - mas considerada por quem?, perguntariam aqueles que desconhecem a língua original - como uma coisa de segunda categoria, quando não um sacrilégio, de forma alguma equivalente ao original.

11 Jakobson, p. 234 [tradução brasileira, p. 67.]

12 Schleiermacher, p. 80: "ein Solches Gedicht ist, seiner eigenthümlichen Natur nach, und in einem noch viel andrem Sinn, als es sich überhaupt von allen Werken grosser Originalitaet sagen lässt, unübersetzar." [tradução: L.D.] 


\subsection{Os textos}

Nos capítulos anteriores, falamos bastante a respeito de texto e tradução, sem definir ao que exatamente estávamos nos referindo. Isto é, de fato, impossível. O texto não se limita ao papel: ele pode apresentar-se noutras formas, pois não quer permanecer lá muito calado. Caso venha a ser traduzido, terá um alcance que de outra maneira não teria, mas precisará vestir-se de outra forma, pois não vai com o seu guarda-roupa habitual a todo e qualquer lugar. $\mathrm{O}$ texto não é um turista que leva a sua carne defumada aonde quer que vá: ele leva somente a si mesmo a diferentes lugares, nos quais talvez tenha que experimentar os frutos exóticos que lá encontrar.

De qualquer maneira, é possível classificar os textos e as traduções, mas somente de forma provisória, pois uma vez que a classificação pareça afinada, as idiossincrasias intratextuais tornarão impossível atribuir a cada grupo uma denominação adequada. Não por coincidência, ambos os grupos são batizados com nomes similares, uma vez que muitos teóricos, como p. ex. Reiss e Vermeer, baseiam suas definições [sobre os tipos de tradução] nos diferentes tipos de texto. Não se trata aqui de bossa nova, pois já a dialética clássica consistia em boa medida na classificação textual, razão pela qual talvez Cícero seja frequentemente considerado o primeiro "teórico da tradução". E, sobretudo depois que Saussure propôs a distinção entre o conteúdo e a expressão, entre a língua em si e o sistema semiológico (langue) que está por trás dela, por um lado, e a realização efetiva desta (parole), por outro, os estudiosos passaram a encarar os fenômenos linguísticos de forma totalmente diferente de antes.

As oposições, fundamento da linguística estruturalista, definem o sentido mediante a existência de unidades que adquirem sentido pelo fato de não serem idênticas entre si. Estas unidades nutrem-se das comparações umas com as outras. Ausentes os polos opostos, os sentidos tornam-se inviáveis. Seria difícil, por exemplo, supor uma definição de raça, caso não se verificasse a existência de negros ou brancos, mas somente de amarelos. A pura e cristalina relação entre opostos nos induz a acreditar que seria possível estudar a língua como se tratássemos de um objeto e explicá-la de forma neutra, como se essa abordagem fosse imune às distorções de natureza ideológica. O problema é que a língua utilizada pelo estudioso é ela própria carregada de sentidos, e o mero ato de falar sobre o fenômeno linguístico empresta sentido às coisas sobre as quais que se fala, assim como a definição da coisa cuida de explicar a natureza da coisa. Assim, a explicação é sempre em alguma medida dada de antemão. 
É neste contexto que devemos compreender a dilatação do conceito de sentido em ambas as direções, a partir da unidade de sentido (signo), composta daqueles elementos linguísticos que Saussure denominou signifié ("significado") e signifiant ("signficante"), e até atingir os elementos mínimos modificadores do sentido (fonemas) ou sistemas de significação mais complexos, p. ex. textos e ideologias. Não se pretende, com essa simplificação, dar conta destas teorias, mas apenas ressaltar que o sentido a ser traduzido é muitas vezes mais difícil de se lidar do que poderia parecer à primeira vista, como p. ex. quando nos detemos nas palavras e em seus possíveis sentidos. Os fonemas, por si só capazes de modificar o sentido, são em geral intraduzíveis, à exceção de umas poucas interjeições. Já os textos são plenamente traduzíveis, mas podem ser entendidos por alguém de forma totalmente diferente da forma como o tradutor a entendeu; neste caso, fenômenos tais como ideologia e tempo podem ser decisivos em termos de sentido. Uma ideologia em decadência é capaz de legar palavras e fluxos de ideias que se interpõem entre o leitor e textos escritos antes que aquele sistema ideológico atinja o seu ápice, seja em termos de palavras ou de ações.

Descontado isso, o sentido mostra-se com frequência algo de difícil manuseio quando se trata de expressar idiossincrasias culturais. O papel desempenhado num texto por estas marcas culturais é bastante variado, abrangendo desde simples informações neutras (p. ex., descrições de lugares ou momentos definidos) até referências pontuais a determinado grupo ou tendência ideológica. Um dos problemas enfrentados pelo tradutor é que tanto um como o outro tipo, isto é, tanto a descrição neutra quanto a referência ideológica, correm o risco de ter seu valor modificado na tradução. Uma descrição neutra pode se tornar "exótica" e sugestiva, e uma jovem vestindo uma saia de palha pode de repente ganhar um sentido totalmente distinto daquele que tem no ambiente cultural do original. Já a referência ideológica pode passar totalmente em branco em virtude da inexistência daquele referente no universo cultural da tradução. Um grupo determinado pode, por exemplo, possuir expressões que remetam à própria situação do grupo no contexto social do texto de partida. Equivalências duvidosas com algum grupo "parecido" existente no universo cultural da tradução, ou puras adaptações, são muitas vezes, e apesar dos pesares, a única opção ao alcance, não oferecendo, porém, qualquer garantia de que o "efeito" obtido será o mesmo.

Por isso mesmo, o tradutor não pode nunca desconsiderar o público-alvo de sua tradução. Ele, assim como os demais indivíduos que conhecem e entendem o ambiente cultural do texto de partida, de alguma forma encontram-se numa posição privilegiada para entender a necessidade de se propor formas alternativas que deem conta das especificidades culturais do texto de partida no âmbito 
cultural da tradução. Isto, porém, é algo de que apenas o tradutor e alguns outros privilegiados têm consciência. O cliente, por sua vez, talvez identifique a diferença entre o texto original e sua tradução, e com base nisso conclui que a tradução é insatisfatória. Ter tato em relação ao público-alvo da tradução significa que o tradutor não deve ser presunçoso a ponto de "simplificar" o texto para que a "plebe" consiga entendê-lo, nem a ponto de forçar o leitor da tradução a consultar um dicionário para conseguir entender algo que os leitores do original são capazes de entender à primeira leitura.

\subsubsection{INTERTEXTUALIDADE}

Um original rico em intertextualidade (ing. intertextuality) torna a vida do tradutor ainda mais encrencada. Exemplos disso são as referências a textos amplamente conhecidos no universo cultural do original. Este tipo de referência ocorre em praticamente todos os tipos textuais (al. Textsorte), e não há autor, publicitário, político ou jornalista, por mais inexperiente que seja, que não possua a sua coleção particular de citações. Não é suficiente lançar mão da tradução de Carlos Alberto Nunes (sem esquecer os demais tradutores) quando um autor de língua inglesa arrota uma citação de Shakespeare, pois nada garante que o público-alvo do texto traduzido atinará com o contexto correto da referência. As possíveis soluções, num caso desses, vão desde a reprodução entre aspas da citação, tal como ela aparece no original, até o uso das notas do rodapé no caso de textos eruditos. Tudo, menos traduzir o trecho tal como o original o oferece.

A intertextualidade é, no entanto, algo mais complexo do que meras referências a textos externos. O tradutólogo islandês Ástráður Eysteinsson fala em "parentextos por afinidade" dando, com isso, especial relevo "[...] à diferença, em termos de efeito, entre o 'texto-sogra' e os respectivos 'textos-genros', que pode fazer com que diferentes leitores percebam, a partir de um mesmo 'texto-mãe', diferentes textos afins, sem que isso signifique que algum deles tenha precedência com relação aos demais" ${ }^{\prime 13}$. Este enfoque no conhecimento prévio (al. Vorwissen) e no conhecimento de mundo (al. Weltwissen) do leitor apenas ressalta que a tarefa do tradutor não se resume a verter frases para uma língua de chegada: ele deve, sobretudo, ser capaz de imbuir-se do original até chegar a compreender os objetivos por trás de cada um de seus componentes individuais.

13 Ástráður Eysteinsson. "Mylluhjólið”, p. 78. (Tradução: L.D.) 
Alguns chegam a definir a própria tradução como intertexto, chamando neste caso o original de pré-texto (al. Prätext) e todos os demais textos dele derivados de pós-textos (al. Folgetext). A tradução seria, portanto, apenas uma das manifestações da intertextualidade, já que pode haver pós-textos dos mais diversos tipos - sátiras, resenhas, adaptações para o teatro ou cinema etc. O importante aqui é o fato de o texto contar com uma espécie de modelo preexistente ou reportar-se a alguma forma de modelo preexistente. Com isso, é evidente que o leitor não pode dar-se ao luxo de fazer vista grossa impunemente a essas referências intertextuais. Estes pequenos detalhes são, com efeito, muito mais importantes do que podem parecer à primeira vista, porquanto ressaltam que os textos são mais do que palavras ditas ou escritas: eles foram concebidos para carrear algo ao leitor de uma maneira bastante específica. As proposições do texto de partida modificam, portanto, o leitor em alguma medida, e isso independentemente de ele simpatizar com o texto ou não, cabendo ao tradutor identificar quais recursos são utilizados para se obter tal resultado e de quais recursos do idioma de chegada ele poderá lançar mão para obter o mesmo resultado. Com isso, entram em jogo mais premissas do que o mero original.

Os teóricos da tradução Katharina Reiss e Hans J. Vermeer definem os textos como "ofertas de informação", atribuindo ao tradutor a missão de propor aos receptores no idioma de chegada o mesmo tipo de oferta com sua tradução ${ }^{14}$. Uma vez que a tradução implica sempre a transposição de especificidades culturais, ou seja, implica transferência cultural (al. kultureller Transfer), talvez fosse possível definir a tradução de textos da seguinte forma: "O aspecto dominante de toda tradução é o seu propósito"

Isso não quer dizer, como acontece com tanta frequência, que o tradutor deva sentar-se e traduzir frase por frase. Não é apanágio da pontuação, que divide as frases do original, pautar a organização sintática do texto traduzido. Cabe, sim, ao tradutor oferecer a mesma informação contida no original da forma mais natural possível na língua de chegada. O que também impõe a necessidade de se desvendar o propósito com que o original fora concebido - isto no caso de o objetivo da tradução não ser justamente o de alterar aquele propósito, p. ex., convertendo uma história escrita para um público adulto numa história infantil.

Esta elucidação dos propósitos do original, da mesma forma que um propósito bem definido para o próprio texto traduzido, provavelmente torna mais

14 Reiss e Vermeer, p. 53-70.

15 Reiss e Vermeer, p. 96: "Die Dominante aller Translation ist deren Zweck." [trad.: L.D.]. 
fácil para o tradutor reduzir os problemas de tradução em problemas menores, para então resolvê-los de cabo a rabo, evitando, com isso, cair nas armadilhas escondidas nos diversos desvãos do original, p. ex., na ordem das palavras ou noutras especificidades linguísticas e culturais, fatores desprovidos de significação na língua de chegada, a não ser naqueles casos em que se pretenda nomeadamente desafiar as especificidades da língua de chegada.

\subsubsection{GÊNERo TEXTUAL E TIPOLOGIA TEXTUAL}

No início do século xix, Friedrich Schleiermacher, o patrono (se descontarmos Lutero) da Teoria da Tradução em língua alemã, classificava a tradução em dois grupos: 1) a tradução de textos literários e acadêmicos; e 2) a interpretação comercial ${ }^{16}$. Apesar das mudanças pontuais verificadas desde aquela época, a mentalidade de muitos teóricos com relação à tradução parece ter mudado muito pouco neste período. Fala-se em tradução literária e em "outros" tipos de tradução. Esta classificação simplória de nada serve caso se pretenda uma abordagem e avaliação textual profissional, seja pela necessidade de se identificar a melhor forma de traduzir um original, seja pela simples necessidade de saber o quanto cobrar por um trabalho.

Tal como anteriormente mencionado, este tipo de classificação textual será sempre provisório, já que é possível identificar uma série de características (al. Merkmale) de um gênero determinado em outros gêneros. Katharina Reiss baseou sua renomada teoria no modelo conhecido como Organon, originalmente proposto pelo linguista de orientação estruturalista Karl Bühler, célebre, entre outras coisas, por sua participação na Escola de Praga, também integrada por Jakobson ${ }^{17}$. A teoria de Bühler, cujas origens podem ser encontradas em Aristóteles, propõe, em poucas palavras, que o signo possui três aspectos principais, a saber: a) descritivo (al. Darstellung); b) expressivo (al. Ausdruck); e c) apelativo (al. Appell). Segundo aquele autor, tais aspectos são decorrentes das funções fundamentais do signo: sintoma (al. Symptom), sinal (al. Signal) e símbolo (al. Symbol) ${ }^{18}$. E, na impossibilidade de traduzir a definição de signo diretamente em termos de uma definição no âmbito da tipologia textual, Reiss classificou

16 Schleiermacher, p. 39-40.

17 Reiss, Katharina. Texttyp und Übersetzungsmethode. Der operative Text. [Obra ainda sem tradução em português.].

18 Cf. Bühler. 
os textos como: 1) informativos (al. informative); 2) expressivos [al. expressive); e 3) operativos (al. operative) $)^{19}$.

Percebe-se, aqui, de imediato, que muitos textos são compósitos de todos estes aspectos, o que não impede o enquadramento de grande parte deles em apenas uma destas categorias, ao menos de forma preponderante. A vantagem disso para o tradutor é a possibilidade de definir para si mesmo o método que melhor se presta a cada situação, e quais formas expressivas mostram-se mais adequadas na língua de chegada. Quando se trata de um texto do tipo informativo, p. ex. um manual de instruções que acompanha um equipamento eletrônico, o tradutor terá a opção de traduzi-lo utilizando um estilo condizente com os usos e costumes da língua de chegada.

Da mesma forma, os textos literários não são apenas expressivos no sentido aqui proposto, e não raro encontramos neles componentes informativo-descritivas e operativas, já que nem todo o aparato utilizado por um autor tem por si só um propósito artístico. Rituais como um funeral ou um casamento, p. ex., são alguns dos eventos mais recorrentes nas obras literárias - no sentido amplo da expressão - nos quais a ladainha padronizada do sacerdote nem sempre apresenta um significado profundo, mas se for traduzida literalmente talvez se desvie daquilo que é percebido como "normal" num funeral ou num casamento [no universo cultural do idioma de chegada]. Em inglês, p. ex., é comum as pessoas dizerem I do [no altar], fórmula que nenhum tradutor em plena posse de suas faculdades mentais se atreveria a traduzir como "eu quero" ou "eu faço".

Ou seja, é altamente provável que seja uma vantagem para o tradutor ser capaz de identificar os propósitos globais do original, além dos objetivos secundários com os quais ele tem que lidar em cada parte do original. Isto lhe permite abordar a obra tal como ele a entende e passá-la adiante da forma que, a seu juízo, é a ideal, já que ninguém, nem o mais refinado artista nem o devorador de normas mais insosso, ninguém inclui algo num texto gratuitamente. É concebível que alguém seja, ao fim e ao cabo, incapaz de elaborar um texto decente, porém o objetivo sempre será elaborar um todo coerente que diga algo em sua coesão. Caso um texto seja propositadamente incoerente ou abrupto, isto indicará que a coesão textual não faz parte dele como deveria. Caso isso ocorra porque o autor é incapaz de algo diferente, então se diz que há "algo de estranho" com o texto, que "falta alguma coisa nele", que o texto não tem "nem pé nem cabeça", e neste caso as devidas correções normalmente acabam sobrando para o tradutor. Se nenhuma

19 Reiss e Vermeer, p. 204-16. 
frase do texto lhe é alheia, como pode ocorrer a alguém que o texto propriamente dito, em sua totalidade, pode ser alheio às suas frases?

\subsection{Teoria da Tradução: filosofia ou filosofice?}

Não são poucos os tradutores profissionais que costumam balançar a cabeça ao ouvir as "bobagens" propostas pelos teóricos da tradução, e muitos deles acrescentam comentários do tipo: "Qual é a utilidade deste tipo de especulação abstrata?”. Isto se explica por várias razões. Em primeiro lugar, a correria do dia a dia não deixa espaço para este tipo de especulação. Em segundo lugar, muitas destas teorias nada mais fazem senão repetir coisas de senso comum. Em terceiro lugar, o possível temor de que a impotência deste ofício seja desmascarada e a roupa suja da profissão seja lavada em público. Em quarto lugar, a desculpa de que as teses propostas pela Teoria da Tradução são tão efêmeras quanto amor de carnaval.

A abundância de postulados teóricos e as encarniçadas polêmicas em torno deles podem facilmente ser atribuídas à complexidade mesma do fenômeno linguístico. $\mathrm{O}$ fracasso da informática em resolver problemas singelos como a tradução eletrônica corroborou a visão de que a linguagem é o repositório de magia mais complexo que o ser humano já engendrou. Se é verdade que equipamentos cada vez mais potentes estão chegando cada vez mais perto de parafrasear textos em outros idiomas, os resultados disto raramente poderiam ser chamados de tradução, sendo necessária a intervenção de um revisor humano para corrigir esses textos, como se eles fossem obra de alguém que volta e meia sofresse de ataques epiléticos em razão dos quais surgem em meio aos textos bobagens e asneiras que a nenhum tradutor ocorreria. Uma das soluções propostas até o momento seria reduzir os originais - de preferência textos informativos altamente especializados - a certas fórmulas verbais que estariam ao alcance do computador traduzir. Isto, porém, suscita algumas questões. Quem determinaria estas fórmulas verbais? E de resto, elas seriam elaboradas levando em conta cada par linguístico, ou seriam permutáveis entre todos os idiomas? (Sendo a última solução naturalmente a mais desejável.)

A dificuldade com a qual todos os teóricos da tradução têm que se haver, por outro lado, é determinar o que é passível de transferência entre idiomas; o que se deve ou não ajustar a uma visão de mundo preexistente. Schleiermacher defendeu, em seu ensaio "Sobre os diferentes métodos de tradução", que haveria apenas duas abordagens fundamentais: "Ou o tradutor deixa o autor onde ele se encontra, levando o leitor até ele, ou ele deixa o leitor onde ele está, e traz o autor 
até ele". ${ }^{20}$ Mesmo que esta receita simples do início do século xIX esteja um passo à frente do que muitos fanáticos da profissão conseguiram percorrer até hoje, ainda assim ela não oferece uma explicação satisfatória do processo traducional e da metodologia nele empregada. E os teóricos continuam tentando superar este impasse com a proposição de novas versões daquela mesma teoria inicial, obtendo, em alguns casos, certos avanços com relação a ela.

Mas o que é então que os tradutores seguem traduzindo, senão uma unidade que é ao mesmo tempo uma totalidade? Não será sua mera possibilidade também fruto da imaginação? Estaria Humboldt certo, apesar de sua tradução do Agamenão? E, afinal, o que é a tradução? Será que ela aceita ao menos ser definida? A Teoria da Tradução ainda não foi capaz de oferecer uma resposta cabal, às vezes lembrando mais a especulação filosófica do que meras instruções sobre como se deve traduzir. A tarefa parece tão complicada como dizer às pessoas como elas devem levar suas vidas: todo mundo sabe como fazê-lo, mas ninguém é capaz de o fazer perfeitamente - as possibilidades parecem infinitas, mas os indivíduos têm que fazer suas escolhas, e quando a razão nos falta, normalmente as ideologias e as religiões se apresentam como uma derradeira tábua de salvação.

\section{A linguagem como tradução}

A relação da tradução com o seu original remete amiúde à imitação platônica da vida pela poesia, imitação da imitação, que Platão queria desterrar de sua República (ao menos aquela produzida por profetas menores), já que ela não preenchia as condições por ele colocadas para os arquétipos enquanto objetos mentais absolutos, isentos de quaisquer opiniões ou ideologias, e assim considerados como autênticos produtos do conhecimento, em contraste com a realidade virtual que não é mais do que uma sombra projetada sobre a parede da caverna onde se encontra um sujeito prisioneiro dos sentidos ${ }^{21}$. Se observamos a tradução desde esta mesma perspectiva, não nos surpreende que ela tenha sido sempre considerada como algo menor do que o original, independentemente de quaisquer considerações de qualidade e prestígio.

Uns defendem que a melhor das traduções possíveis é tão somente o texto original em outro idioma, como Roman Jakobson em seu ensaio supracitado, no qual ele acrescenta ainda: "As línguas diferem essencialmente naquilo que devem

20 Schleiermacher, p. 47.

21 Eyjólfur Kjalar Emilsson, p. 46-47. 
expressar, e não naquilo que podem expressar"22. O único requisito inegociável é a forma - ou seja, a estrutura -, já que o sentido pode ser transposto noutros termos, pois, como Jakobson afirmará mais adiante: "Não há dispositivo gramatical na língua de chegada que torne impossível a tradução literal de toda a informação conceitual contida no original" ${ }^{23}$. Neste sentido, duas observações são cabíveis: primeiramente, parte-se do princípio de que a quantidade de sentidos fundamentais de uma estrutura (senão de uma língua como um todo) é limitada (definida), sendo o mesmo provavelmente verdadeiro em relação à segunda língua. Como contraponto a estes limites, pode-se afirmar que a força criadora da linguagem deve ser sempre a mesma em todas as línguas, tornando com isso válida aquela proposição, a qual, mesmo assim, seguirá suscitando a questão de se se trata aí de tradução ou se simplesmente a nossa definição de tradução está equivocada. Em segundo lugar, pode-se ainda colocar a questão sobre o que estaria abrangido na noção de "informação conceitual" (ing. conceptual information). Como exemplo, podemos citar o caso do soneto, em que a forma guarda, grosso modo, informações sobre o conteúdo: quase sem exceções, trata-se da expressão do poeta, em geral de natureza amorosa ou encomiástica, dirigida a alguma pessoa, e via de regra com uma mudança de perspectiva após o nono verso. Este tipo de informação vincula-se às próprias formas, a partir da tradição que se desenvolva na esteira destas, resultando da interação destas com os conteúdos em delimitações quanto ao tipo de informação que é possível transmitir mediante o recurso às escolhas lexicais, gramaticais ou estilísticas. Porém, as informações devem encontrar vazão em alguma parte, cabendo ao indivíduo decidir se se conformam com este estado de coisas ou se serão compensadas em algum outro ponto do texto. A rigor, Jakobson acaba por afirmar, ao cabo de seu ensaio, que "a tradução é por definição intraduzível"24.

Desta forma, a tradução acaba sempre por assemelhar-se a uma forma de "diluição" da inspiração poética na realidade, sempre seguindo um passo atrás da poesia, sendo portanto inferior a esta, para não entrarmos no mérito da tradução feita a partir de outra tradução. A conclusão, uma vez mais, é no sentido de que a tradução seria, com efeito, inviável.

Ao menos esta é a conclusão de Derrida em seu ensaio "Torres de Babel", uma espécie de introdução a uma discussão sobre o ensaio "A Tarefa do Tradutor"

22 "On the linguistic aspects of translation", p. 236.

23 Ibid., p. 235.

24 Ibid., p. 235. 
de Walter Benjamin ${ }^{25}$. Porém, Derrida propõe uma nova abordagem a este antigo impasse: sua definição precisa da palavra "Babel" deixa claro que ela é intraduzível, mas não de todo - seu significado primário é o de cidade de Deus, sendo secundariamente o nome próprio da cidade (e) da torre que Deus evitou que fosse(m) concluída(s), confundindo a língua de seus habitantes. Desde aquele momento, os homens precisaram "naturalizar" 26 as línguas estrangeiras para conseguir entender-se mutuamente, sendo aquele nome próprio o símbolo de sua confusão ou incompreensão, residindo a contradição no fato de Deus haver dado origem à tradução ao mesmo tempo em que a proibia 27 . "A tradução, portanto, tornou-se necessária e impossível $[\ldots]$..28 . A diferença é tanta que a totalidade incompatível das línguas forma uma base: elas são de fato sempre uma tradução da realidade e de todas as demais. Desta forma, a tradução define-se como uma necessidade básica cuja plena satisfação é uma impossibilidade.

\subsection{Era Deus o Verbo, ou era o Verbo Deus?}

Quiçá não seja mera coincidência que Fausto, ao se ver trancafiado na cela do seu próprio saber, tenha conjurado Mefistófeles na tentativa de parafrasear o início do Evangelho de João. O verbo, o nome, é a ferramenta mental primordial do homem, o primeiro degrau na escadaria da torre, sem o qual os demais seriam inconcebíveis. Os nomes emprestam sentido à realidade e tornam possível aos homens desempenhar os papéis que nela lhes cabem. Por isso, o verbo possui amiúde um significado puro na mente humana, um significado diretamente relacionado a priori ao pensamento e, através dele, à razão pura. Corporificado numa forma durável e prenhe dos sentidos mais sagrados para o homem, o verbo adquire uma tradução múltipla, convertendo-se na explicação da existência de seus leitores e, portanto, em sua justificação. Textos como a Bíblia criam em sua esteira um ambiente espiritual para aqueles que neles acreditam, e ninguém deveria se surpreender com o fato de que o verbo, tal como se insere em textos desta natureza, represente para muitos algo tão sagrado quanto a imagem de um santo.

25 Benjamin, p. 243.

26 Jogo de palavras intraduzível do original: pjóda (nacionalizar, naturalizar) e pýda (traduzir, verter) tem a mesma origem etimológica em islandês. (N.T.)

27 Ibid., p. 249.

28 Ibid. 
Os tradutores costumam ser censurados por duas razões em especial: por traduzir mal e por traduzir literalmente. Essas censuras podem ser atribuídas em parte à polissemia das palavras e em parte aos sentidos carreados pelo receptor da mensagem. Para um fundamentalista, no sentido original da palavra, sem dúvida deve soar bizantino este papo a respeito da contribuição semântica do receptor da mensagem. Não obstante, esta noção apoia-se em dois argumentos. Em primeiro lugar, as palavras sempre estão no lugar de outra coisa, sempre representam algo, já que nunca são a coisa ou o conceito em si, mas apenas a imitação de uma ou de outro. O pensamento e a expressão são também importantes, mas pode-se dizer que constituem apenas métodos para se formular um significado adicional sem precisar torcer as palavras. Aquela imitação provavelmente emergirá sempre igual em todas as circunstâncias, já que o seu usuário não a balbucia gratuitamente, pois tem a pretensão de comunicar algo ao mundo ao seu redor. Sua opinião ou sua necessidade de expressão constituem a motivação a partir da qual aquelas ferramentas são aplicadas. Em segundo lugar, sabe-se que as línguas, e por conseguinte o sentido das palavras, mudam sob a influência do espírito do tempo e do ambiente.

O caráter sagrado que perpassa o verbo jamais será totalmente expurgado, o que não é de todo mal. Este caráter sagrado empresta ao verbo aquela vitalidade necessária para que a expressão tenha efetivamente algum papel a desempenhar no marco da existência humana, um papel que revele à existência o seu verdadeiro propósito. Com João Evangelista, este papel, esta verdade divina original, é corporificado em Jesus - og orððð varð hold ${ }^{29}$ na tradução islandesa de $1919^{30}$, que provavelmente conservou o sentido estrito da palavra carne (isl. hold) recebido de Lutero, apesar de o texto ter sido chamado de "nova versão a partir dos originais" (ný pýding úr frummálunum). Carne apresenta aqui um significado mais inclusivo do que apenas o de que Deus teria descido à Terra em forma de homem: toda a verdade divina ter-se-ia refletido no conjunto da vida, morte e ressurreição de Cristo, em suas palavras e em seus atos, sendo o corpo de Cristo apenas um meio de que Deus se serviu, um meio que atingiu o seu fim ao morrer uma morte simbólica.

Se observamos mais detidamente, o Evangelho de João cumpre uma função diferente da dos outros três evangelhos, pois seu texto realça o aspecto "divino"

29 João 1:15.

30 “[...] e o Verbo se fez carne" (versões Almeida Revista e Corrigida (1898) e Almeida Revista e Atualizada (1956); "A Palavra se tornou um ser humano" na Nova Tradução da Linguagem de Hoje (2000). 
de Cristo por intermédio da mensagem de Deus, palavra do Senhor, e do testemunho dos milagres realizados por Jesus, milagres que se apresentam como prova mundana da caridade e do poder divinos. O Verbo e a Verdade são unos, formam uma mensagem única, que a qualquer pessoa é dada entender mediante símbolos que em si mesmos transcendem todo o entendimento. Todos os textos atribuídos a João Evangelista têm a marca de um doutrinador que tem fé e anseia por difundir a mensagem através daquele que ele sabe ser o mais poderoso de todos os meios, o Verbo. Em seu evangelho, João se utiliza dos dispositivos oferecidos pela dialética, prometendo aos receptores de seu verbo a vida eterna e a ressurreição da carne $e^{31}$, caso aceitem o verbo e o tornem seu.

Para o tradutor, porém, o mais proveitoso é quebrar a cachola tentando entender a maneira pela qual João e seus exegetas deram forma ao Verbo e à sua tradução simbólica, às oposições entre o bem e o mal, entre Deus e o homem, e à manifestação trinitária da verdade divina, que são permanentemente retomados em diferentes textos. Enquanto não for possível conciliar o bem e o mal, seguirá valendo a insistente afirmação de que "o espírito é o que vivifica, a carne para nada aproveita; as palavras que eu [Jesus] vos disse são espírito e vida"32. O espírito convertido em Verbo é o que coaduna a existência humana e o Reino de Deus, sendo isso o que o torna santo - Espírito Santo, amém. As implicações carreadas por este entendimento são, com efeito, extremamente engenhosas. João as formula expressa e claramente no fecho do seu Apocalipse, ou seja, em dois dos versículos finais da Bíblia: "Porque eu testifico a todo aquele que ouvir as palavras da profecia deste livro que, se alguém lhes acrescentar alguma coisa, Deus fará vir sobre ele as pragas que estão escritas neste livro; e, se alguém tirar quaisquer palavras do livro desta profecia, Deus tirará a sua parte do livro da vida, e da cidade santa, e das coisas que estão escritas neste livro" 33 .

\subsection{Ou era o Verbo Arte?}

Walter Benjamin talvez tivesse as recomendações de João Evangelista em mente ao escrever seu ensaio "A tarefa do tradutor" no início do século passado, onde conclui que "A versão interlinear do texto sagrado é o arquétipo ou o ideal

31 João 5: 24-29.

32 João 6:63-64.

33 João 22:18-19. 
de toda tradução" 34 . Essa conclusão é de certa forma surpreendente se pensarmos que o ensaio foi publicado depois de o Curso de Linguística Geral de Saussure ter dado o tom ao estruturalismo, a versão modernista da ciência linguística.

Mas é evidente que Benjamin leu Saussure, já que algumas de suas conclusões não são de todo incompatíveis com aquilo que seria mais caro aos estruturalistas. Segundo ele, que as línguas - ou mais propriamente dito os textos - sejam traduzíveis se deve ao fato de que, "a par de qualquer relação histórica, as línguas não são estranhas entre si, mas são a priori aparentadas, naquilo que pretendem dizer" ${ }^{\prime 3}$. Como descrito anteriormente, trata-se aí, com efeito, essencialmente do mesmo que Jakobson declarara a respeito da tradução em seu conhecido ensaio: todas as línguas têm um propósito em comum, a única diferença sendo a forma como as pessoas dizem as mesmas coisas.

A partir deste ponto, Benjamin e o estruturalismo tomam caminhos divergentes. Ele afirma, no início de seu ensaio, que “tradução é (uma) forma”. Porém, não se trata aqui de forma no sentido preconizado pelos estruturalistas, ou seja, forma como estrutura, porém no sentido mais aproximado da noção aristotélica e até mesmo do apóstolo João, onde a forma se apresenta de fato como o conteúdo, a natureza mesma das coisas, que independe de suas manifestações exteriores. Com isso, ele alforria a tradução do estatuto de imitação subalterna, mas ao mesmo tempo lhe impõe a condição de que siga o original quase que palavra por palavra. Trata-se, é claro, de uma contradição, mas uma contradição diversa daquela que afirmara que as "informações conceituais" são sempre transferíveis de idioma para idioma. Jakobson nos fala de "equivalência na diferença"36, sem, no entanto, esclarecer melhor como seria possível suprir aquela lacuna, ou, nos termos utilizados por Derrida em seu ensaio supracitado: "Jakobson não traduz, ele retoma a mesma palavra: a tradução interlingual ou tradução propriamente dita"37.

Benjamin parte do pressuposto principal de que a obra de arte não é produzida para agradar ao receptor, mas, pelo contrário, como fenômeno totalmente independente em si mesmo: "Nenhum poema se destina ao leitor, nenhum quadro

34 Benjamin, p. 169 [tradução brasileira: p. 32].

35 Ibid., p. 159. Uma tradução alternativa: “[...] as línguas não são estranhas umas às outras, mas, a priori e abstração feita de todas as relações históricas, são entre si aparentadas quanto ao que querem dizer" (apud Furlan, Mauri. "A Missão do Tradutor: Aspectos da concepção benjaminiana de linguagem e tradução". In Cadernos de Tradução n. 1. Florianópolis, Universidade Federal de Santa Catarina, 1996, p. 91-105).

36 Benjamin, p. 233 [tradução brasileira: p. 65].

37 Ibid., p. 252. 
ao observador, nenhuma sinfonia ao ouvinte" 38 . Vemos aqui, estendida à obra de arte, a sacralidade do verbo, que assume aqui um sentido divino diferente daquele dado pelos românticos - os quais punham o próprio artista numa posição central, praticamente como um demiurgo da arte -, segundo o qual é somente através da arte, e não do artista, que o homem consegue comunicar-se com o divino. Pois o artista nada mais é do que um tradutor.

Mas não nos equivoquemos. Benjamin não está tentando aqui uma abordagem teológica, longe disso: o objetivo precípuo de seu ensaio é tratar da tarefa do tradutor, da matéria a ser traduzida e, por conseguinte, da metodologia a ser adotada na tradução. Assim, ele não parte da premissa de que o mais importante seja identificar o que o autor do original "quis dizer", nem muito menos transmitir o "sentido" do original, mas, sim, o seu conteúdo, conteúdo este que deve ser depreendido da língua de partida. Trata-se aqui de uma noção original de fidelidade, alheia ao sentido corriqueiro deste conceito, cujas bases talvez sejam a visão de Benjamin da linguagem, não como um conjunto de unidades estruturais isoladas, mas como uma parte viva de uma linguagem maior ${ }^{39}$. Ao mesmo tempo, a questão sobre a possibilidade ou impossibilidade da tradução provavelmente emergirá com ainda maior pertinência.

Benjamin sai desta sinuca de bico apelando a João Evangelista - "No princípio era o Verbo" ${ }^{40}$ - e com isso rejeita a ideia de que a tradução não pode "saber a tradução": "A verdadeira tradução é transparente, não cobre o original, não lhe deita sombras, mas, antes, faz com que caia em toda sua plenitude sobre este a língua pura, como que fortalecida por sua mediação" ${ }^{41}$. A razão mais sólida por

38 Ibid., p. 156: "Den kein Gedicht gilt dem Leser, kein Bild dem Beschauer, keine Symphonie der Hörerschaft."

39 Ibid., p. 165.

40 João 1:1.

41 Benjamin, p. 166: "Die wahre Übersetzung ist durchscheinend, sie verdeckt nicht das Original, steht ihm nicht im Licht, sondern lässt die reine Sprache, wie verstärkt durch ihr eigenes Medium, nur um so voller aufs Original fallen." A tradução reproduzida foi retirada de Monegal, Emir Rodríguez, "Prólogo", in Transblanco (em torno a Blanco de Octavio Paz) de Paz, Octavio e Campos, Haroldo de. Rio de Janeiro, Guanabara, 1986, p. 11-17. Traduções alternativas desta mesma citação: "A verdadeira tradução é transparente, não encobre o original e não o tira da luz: ela faz com que a pura língua, como que fortalecida por seu próprio meio, recaia ainda mais inteiramente sobre o original." [Scholem, Gerschom. "Walter Benjamim und sein Engel”. In Lages, Susana K. Walter Benjamim. Traducão e Melancolia. São Paulo, Edusp, 2002, p. 224, apud Zuccarello, Maria Franca. "La Ciociara de Alberto Moravia: tradução e negociação", in Cadernos do x Congresso Nacional de Linguística e Filologia (em homenagem a Antenor Nascentes), v. x, n. 5 (Línguas Estrangeiras). Rio de Janeiro, Círculo Fluminense de Estudos Filológicos e Linguísticos, uerJ, 
trás deste argumento não se esgota apenas no fato de que a maioria das traduções dignas deste nome expande centrifugamente os horizontes da língua de chegada, como Benjamin assevera: Em todas as linguas e em todas as suas obras e imagens, para além daquilo que se pode comunicar existirá algo não comunicável, algo, que de acordo com a contextura em que se encontra, será ou um Simbolizante ou um Simbolizado ${ }^{42}$.

Se é verdade que o símbolo e a coisa simbolizada nos remetem às componentes básicas do signo segundo Saussure, Benjamin agrega, no entanto, uma terceira dimensão, ou uma "terceira essência", e o converte num todo unificado: a tríade semiótica, fruto de oposições. O tempo (limitado) e a eternidade (ilimitada) são conceitos que ganham sentido um em relação ao outro, da mesma forma que o bem e o mal: um é inconcebível sem o outro. A natureza da arte constitui o cerne do pensamento benjaminiano e também o cerne da linguagem pura - natureza presente a um só tempo no signo e na coisa significada, sendo o signo a manifestação visível, e a coisa significada uma tentativa de representar o cerne da expressão em gestação. $O$ fato de este cerne referir-se ao signo que o representa empresta-lhe ainda uma pesada carga de sentidos alheatórios e de

2006.]. "A verdadeira tradução é transparente, não recobre o original, mas deixa transparecer a língua pura do original. Ela é um complemento do texto original; um complemento muito importante porque na tradução o original desenvolve-se até um nível superior" [Afonso, João Santos. "História e tipologia da tradução", in Tradução e comunicação. A Teoria da Tradução como ciência. Tese apresentada no mestrado em Ciências da Comunicação. Universidade da Beira Interior, 1998, apud Augusto Aires Nascimento, "Traduzir, verbo de fronteira nos contornos da Idade Média", in Vários. O Género do Texto Medieval. Lisboa, Cosmos, p. 121].

42 Ibid., p. 166: "Es bleibt in aller Sprache und ihren Gebilden ausser dem Mitteilbaren ein NichtMitteilbares, ein, je nach dem Zusammenhang, in dem es angetroffen wird, Symbolisierendes oder Symboliesertes". A tradução reproduzida acima foi retirada de: Benjamin, Walter. "A tarefa do tradutor". Trad. Fernando Camacho. In Castello Branco, Lucia (org.) A tarefa do tradutor, de Walter Benjamin. Quatro traduções para o português. Belo Horizonte, Fale/UfmG, 2008, p. 39. Traduções alternativas desta mesma citação retiradas dessa mesma coletânea: "Em todas as línguas e suas obras permanece, fora do comunicável, um incomunicável, segundo a relação em que se encontra algo de simbolizante ou simbolizado.” (Op. cit. "A tarefa do tradutor". Trad. Karlheinz Barck. Ibid, p. 62-3). "Em todas as línguas e em suas construções resta, para além do elemento comunicável, um elemento não comunicável, um elemento - dependendo do contexto em que se encontra - simbolizante ou simbolizado." (Op. cit. "A tarefa-renúncia do tradutor". Trad. Susana Kampff Lages. Ibid, p. 78). "Em toda a linguagem e nas suas criações resta, para lá do que é comunicável, um não comunicável, um simbolizante e um simbolizado, dependente do contexto em que se situa.” (Op. cit. "A tarefa do tradutor". Trad. João Barrento. Ibid, p. 95). Agregamos ainda uma última tradução alternativa, retirada de outra obra: "Resta em todas as línguas e em suas composições, afora o elemento comunicável, um elemento não comunicável, um elemento que - dependendo do contexto em que se encontra - é simbolizante ou simbolizado" (Benjamin, Walter, "A tarefa do tradutor". Trad. Susana Kampff Lages. In Benjamin, Walter. Escritos sobre mito e linguagem - 1915-1921. Org., apres. e not. Jeanne Marie Gagnebin. Trad. Susana Kampff Lages e Ernani Chaves. São Paulo, Duas Cidades/Editora 34, 2011, p. 116). 
influências peregrinas: Libertá-la desse significado, e tornar o Simbolizante no próprio Simbolizado, restaurando a Lingua pura que é formada no movimento da lingua, constitui o unico mas possante poder do tradutor ${ }^{43}$.

\section{A produção textual}

Palavras não são apenas palavras, mas paisagens num mundo a que chamamos texto. A leitura de um texto é uma tentativa de vivenciar aquele mundo de texto. Se o leitor extraviar-se-á ou não em sua jornada por aquele mundo é algo que depende de vários fatores, ainda que dependa principalmente dos conhecimentos linguísticos e da amplitude mental tanto de quem gera como de quem absorve o texto. E isto não diz respeito necessariamente apenas a textos de maior prestígio, p. ex. às belas-letras ou às sagradas escrituras, por mais que um belo soneto possa, com menor esforço, proporcionar ao leitor incomparavelmente maior satisfação espiritual do que os complicados manuais de instrução que costumam acompanhar os aparelhos eletrônicos.

Mas qual seria, então, a diferença entre o original e a tradução? E o que é esse tal de original, exatamente? Responder essas questões não é tão simples quanto possa parecer. Para começar, muitos autores distinguem as traduções intralinguísticas das traduções interlinguísticas, sendo Jakobson, que as classifica em três categorias, um bom exemplo disso:

43 Ibid., p. 167: "Von diesem sie zu entbinden, das Symbolisierende zum Symbolisierten selbst zum machen, die reine Sprache gestaltet in der Sprachbewegung zurückzugewinnen, ist das gewaltige und einzige Vermögen der Übersetzung." A tradução reproduzida foi retirada de: Benjamin, Walter, "A tarefa do tradutor". Trad. Fernando Camacho. In Castello Branco, Lucia (org.) A tarefa do tradutor, de Walter Benjamin. Quatro traduçoes para o português. Belo Horizonte, Fale/UFMG, 2008, p. 39-40. Traduções alternativas desta mesma citação retiradas dessa mesma coletânea: "Desvinculá-la desse sentido, fazer do simbolizante o simbolizado, mesmo recuperar a língua pura configurada no movimento verbal, é o violento e único poder da tradução." (Op. cit. "A tarefa do tradutor". Trad. Karlheinz Barck. Ibid, p. 63). "Desvinculá-la desse sentido, transformar o simbolizante no próprio simbolizado, recobrar a pura língua plasmada no movimento da linguagem - esse é o único e grandioso poder da tradução." (Op. cit. "A tarefa-renúncia do tradutor". Trad. Susana Kampff Lages. Ibid, p. 78). "E a tradução é aquele meio, poderoso e único, capaz de libertar a língua pura do peso do sentido, de transformar o simbolizante no próprio simbolizado, de recuperar a língua pura, esteticamente configurada, para o movimento da linguagem." (Trad. João Barrento. Ibid, p. 95). Agregamos ainda uma última tradução alternativa, retirada de outra obra: "Desvinculá-la desse sentido, transformar o simbolizante no próprio simbolizado, recobrar a pura língua plasmada no movimento da linguagem - esse é o único e colossal poder da tradução" (Benjamin, Walter, "A tarefa do tradutor". Trad. Susana Kampff Lages. In Benjamin, Walter. Escritos sobre mito e linguagem - 1915-1921. Org., apres. e not. Jeanne Marie Gagnebin. Trad. Susana Kampff Lages e Ernani Chaves. São Paulo, Duas Cidades/Editora 34, 2011, p. 116). 
1 A tradução intralingual ou reformulação (rewording) consiste na interpretação de signos verbais por meio de outros signos da mesma língua.

2 A tradução interlingual ou tradução propriamente dita consiste na interpretação dos signos verbais por meio de alguma outra língua.

3 A tradução intersemiótica ou transmutação consiste na interpretação dos signos verbais por meio de sistemas de signos não verbais ${ }^{44}$.

Estas definições, amplamente conhecidas nos círculos da teoria da tradução, são, no entanto, bastante abertas, se as observamos com mais atenção. A primeira pode abarcar quaisquer tipos de elaboração a partir de um original ou pré-texto, dramatização, adaptação ou a edição diplomática de manuscritos anteriores à era da imprensa. A existência de diferentes edições "definitivas" feitas a partir de um mesmo manuscrito original demonstram que os resultados deste tipo de elaboração dependem de fatores os mais variados, como pressupostos ideológicos, condições orçamentárias etc. O melhor exemplo de tradução intralinguística no âmbito da cultura islandesa talvez seja Gerpla, de Halldór Laxness, onde as premissas ideológicas da Saga dos Irmãos Jurados ${ }^{45}$ são reelaboradas: ao invés da visão do seu anônimo autor original, Laxness imprimiu à obra a visão romântica do século XIX, quando heróis degredados cavalgavam de comarca em comarca em busca de refúgio ${ }^{46}$.

A segunda definição somente não é uma repetição, como Derrida afirmou, porque agrega uma pequena - mas fundamental - componente, a saber, a "interpretação", a qual, no entanto, infiltra uma contradição na argumentação estruturalista de Jakobson, já que aqui o caráter individualista da tradução ganha um relevo especial. A interpretação, determinada que é por circunstâncias específicas de tempo e espaço, tem um impacto decisivo na tradução: dada a estabilidade do original, resta com isso explicada a possibilidade de infinitas traduções a partir de um mesmo texto de partida. O texto renova-se em cada tradução que dele se faz, e no limite pode-se argumentar que até o próprio original é diferente a cada vez que é reimpresso, ou será que não há nenhuma diferença entre as edições de Halldór

44 Jakobson, p. 233 [tradução brasileira: p. 64-65].

45 No orig.: Fóstbradra saga.

46 Dom Quixote pode ser citado com um exemplo de tradução intralinguística no contexto ibérico, em que Cervantes parodia um gênero literário que já se encontrava em pleno ocaso, os romances de cavalaria. No âmbito da literatura brasileira, um exemplo seria a "Canção do Exílio", de Gonçalves Dias, provavelmente o texto mais parodiado em toda nossa história literária, reescrito que foi por escritores e compositores tão diversos quanto Oswald de Andrade, Carlos Drummond de Andrade, Murilo Mendes, Vinícius de Moraes, José Paulo Paes, Chico Buarque de Holanda e Moraes Moreira. (N.T.) 
Laxness bancadas pelo proprietário de uma manteigaria nos idos de 1930 e aquelas que os estudantes do terceiro milênio têm em suas mãos? A própria apresentação gráfica, além do conhecimento acumulado sobre a criação e recepção do texto e sobre a biografia de seu autor, tudo isso faz dele um texto diferente do original que viu a luz pela primeira vez.

Por outro lado, a relação extremamente íntima do original com seu autor pode resultar às vezes enganosa, não porque o autor e sua biografia sejam de somenos, ou porque o texto, uma vez disponível, seja apenas um tipo de argila que se pode moldar ao bel-prazer, mas sim porque as ideias que fazemos de um e de outro, e que influenciam na interpretação do original, são frequentemente formadas de antemão. Além disso, em muitos casos, a própria autoria ou o que o autor quis dizer é controverso, sendo os textos antigos um bom exemplo neste sentido. As obras de Aristóteles, os autores bíblicos, Snorri Sturluson, para citarmos apenas uns poucos, chegaram até nós por outras mãos. Muitas vezes, vários séculos, quando não milênios - como no caso aristotélico - podem ter transcorrido entre a composição do original e o manuscrito mais antigo preservado, e ninguém com um mínimo de juízo pretenderá afirmar que estes textos tenham chegado até nós exatamente como foram redigidos por seu autor original. Os filólogos podem até ter chegado, afinal, a um consenso quanto à edição "correta" daqueles textos, a qual, porém, nada mais é, mesmo em sua língua de partida, do que uma tradução intralinguística obtida com base na interpretação científica de materiais empíricos disponíveis, ou seja, são obra de cientistas, e não de seu "autor".

\subsection{Leitura enquanto interpretação}

A interpretação textual tem início com a leitura ou outra forma de recepção, a qual pode ser tão intensa a ponto de inspirar outro texto. O leitor, de certa forma, coloca-se numa situação semelhante à do autor ao escrever o texto. O processo criativo do leitor consiste em sua tentativa de criar uma imagem do texto em sua mente, ajustando-o ao seu próprio marco ideológico e lutando para identificar o que o texto pretende de si. Caso o texto ofereça alguma ameaça à integridade ideológica do leitor, ele o rejeitará, mesmo que apenas em parte, ou então ajustará a sua malha ideológica de forma a dar conta dele.

O sentido do texto dificilmente é... Ele apenas começa a adquirir seu sentido quando recebido de alguma forma, e somente passa a exercer influência quando os indivíduos começam a falar dele ou então a mudar sua forma de pensar 
e seu comportamento em virtude dele. Este nível de influência somente é exercido por uma quantidade restrita de textos, enquanto a maioria deles é apenas parte de um sistema textual mais amplo no âmbito de um sistema ideológico, o qual, por sua vez, não constitui uma totalidade lógica, mas cujo propósito e obstáculos refletem-se nos textos escritos em cada época ${ }^{47}$. Porém, ao contrário dos sistemas textuais, as pessoas devem receber textos individuais como uma totalidade, caso pretendam entendê-los enquanto unidades textuais. Isto é melhor compreendido à luz de um exemplo: a Bíblia é um sistema textual que apenas uma minoria leu de ponta a ponta, mas tem, no entanto, um impacto muito maior do que este fato poderia indicar no sistema ideológico dos povos cristãos.

O único texto genuinamente ininteligível é o texto absolutamente ignorado e caído no ostracismo. Nisto, ele é equivalente ao texto jamais escrito. Na medida, porém, em que é lido, o texto adquire significado, um significado que não raro transcende o limitado âmbito da realidade vivenciada por seu leitor. É o significado que infunde vida num texto, o significado é a vida do texto, da mesma forma que é a vida do idioma, e seguirá vivo enquanto o texto continuar sendo lido. Em vista disso, é possível endossar as palavras de Guðbergur Bergsson quando ele afirma: "Conseguir induzir a mente de outros a interpretar e atribuir sentido é mais importante para uma obra literária do que saber o que teria levado o autor a publicá-la" do escritor em forma de palavras, a lua que recebe a luz do sol da existência no universo daquele" ${ }^{49} \mathrm{e}$, por conseguinte, intimamente ligado ao escritor enquanto pessoa.

Quiçá as pessoas escrevam apenas para manter vivos certos personagens, autores ou não autores, cf. os sonetos de Shakespeare, os quais, de fato, mantêm o nome dele mais em evidência do que as personagens que ele pretendia elogiar. Quiçá as pessoas leiam para conhecer essas personagens e, caso a obra seja boa, pode ser que venham a conhecer melhor os outros e a si mesmas, e é isso o que eu considero a verdadeira leitura, quando o leitor afinal chega a entender o texto completamente, identificando-se com ele de alguma forma. Essa identificação é indispensável para quem tencione traduzir uma obra literária da melhor forma possível, pois facilita a tarefa do tradutor, dando-lhe segurança para que ele possa dizer com as suas próprias palavras aquilo que entende.

\footnotetext{
47 Cf. Lefevere, p. 11-40.

48 Guðbergur Bergsson, p. 51.

49 Ibid.
} 


\subsection{Ao fim e ao cabo, traição?}

Um batido lugar-comum - o adágio italiano traduttore, traditore - dá por favas contadas que o tradutor é o traidor do autor. Em vista disso, seria possível argumentar metaforicamente que o destino manifesto do tradutor talvez seja fazer as vezes de um Judas e trair o autor com um beijo, apresentando a este a desculpa de que, sem ele, da mesma forma que sem Judas, a obra jamais seria perfeita.

Porém, trata-se aqui de um equívoco. A traição ao autor só poderia se configurar na forma pela qual o tradutor realiza a sua tarefa. Agindo assim, ele também estaria traindo os próprios leitores. $\mathrm{O}$ autor e o tradutor precisam necessariamente convergir de alguma forma no espaço interpretativo, espaço que pode ser redefinido infinitas vezes. Cabe ao tradutor explorar este espaço interpretativo, armado de todo o conhecimento e de todas as ferramentas de apoio (eventualmente) ao seu dispor. Agindo desta forma, ele poderá dar fé, perante o autor e aos leitores, de ter agido com a fidelidade necessária para interpretar o texto corretamente como lhe correspondia.

\section{Referências bibliográficas}

ÁstráĐur Eysteinsson. "Mylluhjólið. Um lestur og textatengsl.” Tímarit Máls og menningar [“'O moinho. Leitura e intertextualidade”. Revista Lingua e Cultura. Reykjavík], 4 (1993): 73-85. Benjamin, Walter. "Die Aufgabe des Übersetzers.” In: Störig, p. 156-169. [trad. bras.: a) "A Tarefa do Tradutor". Trad. Dirce Riedel, Karlheinz Barck et al. In: Cadernos do Mestrado/Literatura. Vol. 1. 2. ed. rev. e aum. Rio de Janeiro: Instituto de Letras/UerJ, Editora da UerJ, 1994, p. v-xii. Trad. por um grupo de alunos de pós-graduação em Literatura Brasileira do Instituto de Letras da Uerj e rev. por Johannes Kretschmer. b) "A tarefa do tradutor". Trad. Susana Kampff Lages. In: Clássicos da teoria da tradução. Antologia bilíngue. V. 1 - Alemão-português. Org. Werner Heidermann. Florianópolis: Universidade Federal de Santa Catarina, Núcleo de Pesquisas em Literatura e Tradução, 2001, p. 211-2.] [trad. port.: a) "A tarefa do tradutor". In: Obras Escolbidas de Walter Benjamin. Vol. 5. Trad. de João Barrento. Lisboa: Assírio \& Alvim, a publicar. b) "A tarefa do tradutor". Trad. Fernando Camacho. In: Humboldt. München, F. Bruckmann, 19 (40): 38-45, 1979.] [trad. cast.: "La tarea del traductor". In: Vega, p. 285-296.]

Biblía, pað er heilög ritning. Ný pýding úr frumálunum. London/Reykjavík: British and Foreign Bible Society, 1919. [trad. isl. da Bíblia]

Die Bibel, nach der Übersetzung Martin Luthers. Stuttgart: Deutsche Bibelsgesellschaft, 1985. [trad. al. da Bíblia]

Derrida, Jacques. "Des Tours de Babel." A Derrida Reader. Between the Blinds. Ed. e notas de Peggy Kamuf. Trad. ing. Joseph F. Graham. New York o.v.: Harvester \& Wheatsheaf, 
1991, 224-253. [trad. bras.: Torres de Babel. Trad. Junia Barreto. Belo Horizonte: Editora UFMG, 2002]

Eyjólfur KJalar Emilsson. “Inngangur.” Í Ríki Platóns. 9-77. Reykjavík: Hið íslenska bókmenntafélag, 1991. [intr. à trad. isl. de A República de Platão publ. pela Sociedade Literária Islandesa]

GuĐbergur Bergsson. “Skáldasagnahöfundurinn og textinn. ‘Óttinn’ við textann.” Tímarit Máls og menningar. [“O escritor e o texto. O 'medo' do texto”. Revista Lingua e Cultura], 1 (1993); 51-61.

Humboldt, Wilhelm von. "Einleitung zu Agamennon.” In: Störig, p. 71-96. [trad. bras.: "Introdução a Agamêmnon". Trad. de Susana Kampff Lages. In: Clássicos da teoria da tradução. Antologia Bilíngue. Vol. 1 - Alemão-português. Org. Werner Heidermann. Florianópolis: Universidade Federal de Santa Catarina, Núcleo de Pesquisas em Literatura e Tradução, 2001, p. 90-105].

JAKOBSOn, Roman. “On Linguistic Aspects of Translation.” In: On Translation. Ed. Reuben A. Brower. 2. ed. (1959). New York, Oxford University Press, Galaxy, 1966, 232-239. [trad. bras.: "Aspectos linguísticos da tradução". In: Linguística e comunicação. Pref. de Isidoro Blikstein. Trad. de José Paulo Paes. São Paulo: Cultrix, 1972, p. 63-72.] [trad. cast.: "En torno a los aspectos lingüísticos de la traducción”. In: Ensayos de lingüística general. Barcelona, Planeta-Agostini, 1985, p. 67-77].

KOLLER, Werner. Einführung in die Übersetzungswissenschaft. 4. ed. rev. Heidelberg/Wiesbaden: Quelle und Meyer, 1992.

Lefevere, André. Translation, Rewriting and the Manipulation of Literary Fame. London e New York: Routledge, 1992.

Lutero, Martinho. "Sendbrief vom Dolmetschen.” In: Störig, p. 14-32. [trad. bras.: a) "Carta aberta do doutor Martinho Lutero a respeito da Tradução e da Intercessão dos Santos”. Trad. Walter O. Schlupp. In: Obras Selecionadas [de] Martinho Lutero - vol. VIII: Interpretação bíblica. Ed. Nestor Beck. Porto Alegre, Concórdia; São Leopoldo, Sinodal, 1995, p. 205-220. b) "Sendbrief vom Dolmetschen/Carta aberta sobre a tradução." 'Trad. Mauri Furlan. In: Clássicos da Teoria da Tradução. Antologia Bilíngue. Vol. 4-Renascimento. Org. Mauri Furlan. Florianópolis: Universidade Federal de Santa Catarina, Núcleo de Pesquisas em Literatura e Tradução, 2006, p. 94-131] [trad. cast.: “Circular sobre la traducción”. In: Vega, p. 105-112].

NIDA, Eugene A. Taber, Charles R. The theory and practice of translation. Leida, E.J. Brill, 1969. [trad. cast. La traducción: teoría y práctica. Trad. e adapt. A. de la Fuente Adánez. Madrid: Cristiandad, 1986].

Platão. Ríkið. Trad. isl. Eyjólfur Kjalar Emilsson e Kristján Árnason. Reykjavík: Hið íslenska bókmenntafélag, 1991. [trad. isl. de A República de Platão publ. pela Sociedade Literária Islandesa].

ReIss, Katharina. Texttyp und Übersetzungsmethode. Der operative Text. Heidelberg, Max Niemeyer, 1976. 
ReIss, Katharina. vermeer, Hans J. Grundlegung einer allgemeinen Translationstheorie. 2. ed. Tübingen: Max Niemeyer, 1994. [trad. cast.: Fundamentos para una teoría funcional de la traducción. Trad. S. García Reina, C. Martín de León e H. Witte. Madri, Akal, 1996].

SchreIBER, Michael. Übersetzung und Bearbeitung. Zur Differenzierung und Abgrenzung des Übersetzungsbegriffs. Tübingen, Narr, 1993.

SCHLEIERMACHER, Friedrich. "Ueber die verschiedenen Methoden des Übersetzens." In: Störig, p. 38-70. [trad. bras.: "Sobre os diferentes métodos de tradução", trad. Margarete von Mühlen Poll. In: Clássicos da Teoria da Tradução. Antologia bilíngue. Vol. 1 - Alemão-português. Org. Werner Heidermann. Florianópolis: Universidade Federal de Santa Catarina, Núcleo de Tradução, 2001]. [trad. port.: Sobre os diferentes métodos de traduzir. Apres., trad., notas e pref. J.M.M. Justo. Porto: Elementos Sudoeste, 2003]. [trad. cast.: "Sobre los diferentes métodos de traducir". In: Vega, p. 224-235].

STOLZE, Radegundis. Übersetzungstheorien. Eine Einhführung. Tübingen, Narr, 1994.

STÖRIG, Hans Joachim (Ed.). Das Problem des Übersetæens. Ed. Hans Joachim Störig. Darmstadt, Wissenschaftliche Buchgesellschaft, 1963.

VEgA, Miguel Ángel (Ed.). Textos clásicos de teoría de la traducción, Madrid: Cátedra, 1994. 